\title{
Slapped in the Face by the Invisible Hand: Banking and the Panic of $2007^{+}$
}

\author{
Gary Gorton \\ Yale and NBER \\ Prepared for the Federal Reserve Bank of Atlanta's 2009 Financial Markets Conference: Financial \\ Innovation and Crisis, May 11-13, 2009
}

This version: May 9, 2009

\begin{abstract}
The "shadow banking system," at the heart of the current credit crisis is, in fact, a real banking system and is vulnerable to a banking panic. Indeed, the events starting in August 2007 are a banking panic. A banking panic is a systemic event because the banking system cannot honor its obligations and is insolvent. Unlike the historical banking panics of the $19^{\text {th }}$ and early $20^{\text {th }}$ centuries, the current banking panic is a wholesale panic, not a retail panic. In the earlier episodes, depositors ran to their banks and demanded cash in exchange for their checking accounts. Unable to meet those demands, the banking system became insolvent. The current panic involved financial firms "running" on other financial firms by not renewing sale and repurchase agreements (repo) or increasing the repo margin ("haircut"), forcing massive deleveraging, and resulting in the banking system being insolvent. The earlier episodes have many features in common with the current crisis, and examination of history can help understand the current situation and guide thoughts about reform of bank regulation. New regulation can facilitate the functioning of the shadow banking system, making it less vulnerable to panic.
\end{abstract}

+ This paper draws on a number of current research projects with several coauthors. I acknowledge their influences on my thinking and thank them: Tri Vi Dang, Bengt Holmström, and Andrew Metrick. In particular, I thank Bengt Holmström for reminding me of the relevance of my own work with George Pennacchi when he discussed Gorton (2008). For help with data I thank Craig Furfine, Richard Grossman and various participants in the capital markets. Thanks to James Aitken, David Andolfatto, Charles Calomiris, Tri Vi Dang, Richard Grossman, Ping He, Ananth Krishnamurthy, Maury Obstfeld, Maureen O'Hara, Ashraft Rizvi, Rich Rosen, Gabe Rosenberg, Amit Seru, and Manmohan Singh for comments. 


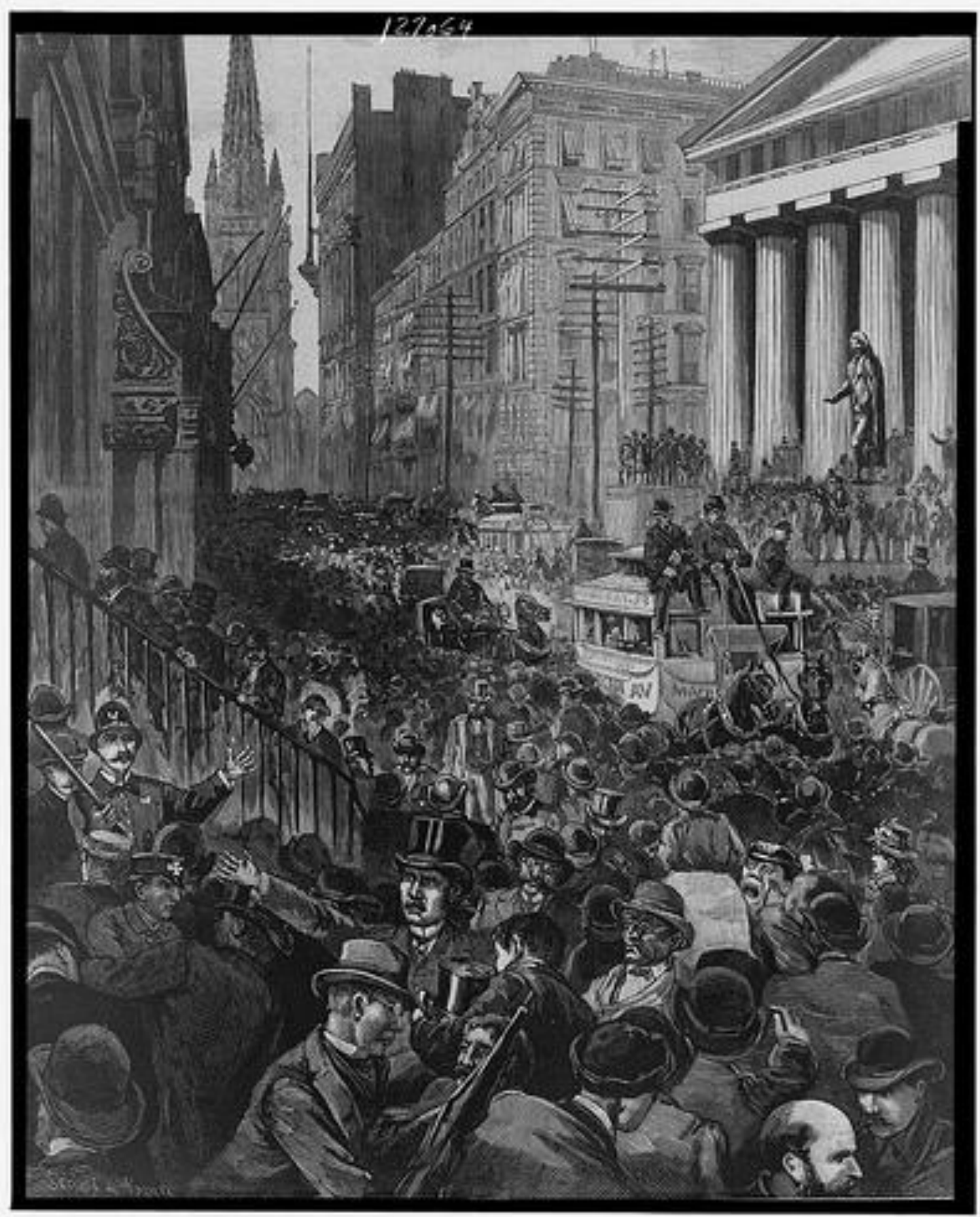

"The Panic - Scenes in Wall Street Wednesday Morning," May 14, 1884, Harper's Weekly, vol. 28, no. 1431, p. 333; drawn by Schell and Hogan. 
"The American panic of 1907 ... gave the lie directly to those who in recent years have contended that we should never again witness experiences like those of the memorable years 1837, 1857, 1873, and 1893." Andrew (1908a, p. 290).

Economists view the world as being the outcome of the "invisible hand," that is, a world where private decisions are unknowingly guided by prices to allocate resources efficiently. ${ }^{1}$ The credit crisis raises the question of how it is that we could get slapped in the face by the invisible hand. What happened? Many private decisions were made, over a long time, which created the shadow banking system. That system was vulnerable to a banking panic. The U.S. had a banking panic starting in August 2007, one that continues today. But banking panics, you say, like the one in the movie "It's a Wonderful Life," don't happen anymore. ${ }^{2}$ Indeed, until these recent events, most people did not think of banking panics as something to be concerned about. After all, the panics of the Great Depression are a dim memory. Since 1934 when deposit insurance was adopted, until the current panic - a span of almost 75 years there had been no banking panics.

The period from 1934, when deposit insurance was enacted, until the current crisis is somewhat special in that there were no systemic banking crises in the U.S. ${ }^{3}$ It is the "Quiet Period" in U.S. banking. See the figure below. ${ }^{4}$ The figure shows the Great Depression very dramatically, but this event was very special, as discussed below. Looking at the figure, the Quiet Period in banking following the Great Depression is also clear. This Quiet Period led to the view that banking panics were a thing of the past. The year 2008 does not show much because the figure is in terms of number of failures, not total assets of failed institutions; and it does not include failed investment banks or distressed mergers.

The period of quiescence is related to what macroeconomists call "The Great Moderation," a view associated with the observation that the volatility of aggregate economic activity has fallen dramatically in most of the industrialized world. ${ }^{5}$ One explanation for this is that there were no longer banking panics. ${ }^{6}$ From a longer historical perspective, however, banking panics are the norm in American history. And, obviously now the world is different; recent events are likely to lead to a revision of this view.

\footnotetext{
${ }^{1}$ Famously due to Adam Smith, The Wealth of Nations, Book IV, Ch. II, page 484-485 (Modern Library Edition, New York).

${ }^{2}$ In this well-known movie, starring Jimmy Stewart, there is a run on the local savings bank in the fictional town of Bedford Falls. It is not a systemic event, but it seems to correspond to most people's idea of a "banking panic."

${ }^{3}$ The savings and loan crisis was costly, $2 \%$ of GDP, but was not a systemic event since it was confined to a particular group of institutions facing the same regulations.

${ }^{4}$ The figure shows the number of bank failures, rather than total assets of failed banks, or fraction of banks failing. This is due to data limitations. The Panic of 1893 is visible in the figure, and also the recession starting in July 1990. 5 There is a large literature on "The Great Moderation." For a survey of some of the empirical evidence, see Summers (2005). For a survey of the literature, see Stock and Watson (2002). Gali and Gambetti (2008) is a recent paper.

${ }^{6}$ The most common explanations for the Great Moderation fall into one of three categories: better monetary policy, changes in inventory management, and good luck. Ironically, the idea that the Great Moderation might have something to do with the financial system is not something even contemplated by economists, despite the evidence that banking shocks have significant effects on economic growth. See, e.g., Bernanke (1983), Boyd, Kwak, and Smith (2005), Cerra and Saxena (2008), Valencia (2008), and Levintal (2008).
} 
What gave us almost 75 years of relative quiet in banking? What has changed? How could problems in one part of the housing sector cause a banking panic in the $21^{\text {st }}$ century? The banking system metamorphosed in the last twenty-five to thirty years and this transformation re-created the conditions for a panic. But, what does that mean exactly? What is the "shadow banking system"? Understanding that the shadow banking system is, in fact, real banking and that current events constitute a banking panic is vital to thinking about the future of the financial system. The failure to understand the transformation of banking has led to a great deal of confusion about the state we are in now. The functions of "banks" and "banking" remain, and these must be understood to see how a banking panic can occur. Understanding this is the only reasonable basis for new policies.

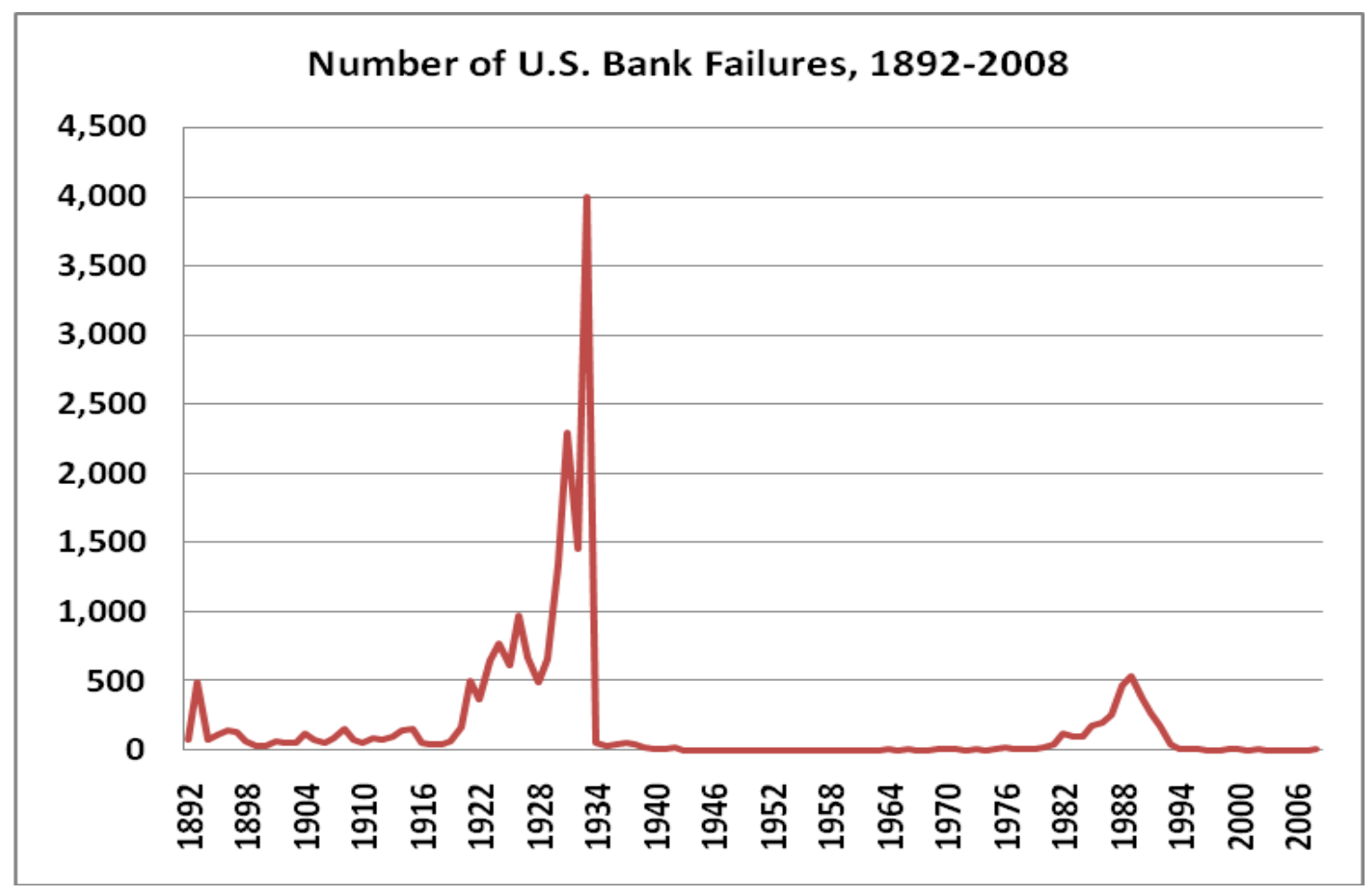

Source: Banking and Monetary Statistics and FDIC.

The lived experience of the current banking panic is confusing, and the reality of what has happened is hard to accept. The concept of a "systemic event" seems somewhat vague, seemingly referring casually to "bad things" happening. It is important to be clear on this. A banking panic means that the banking system is insolvent. The banking system cannot honor contractual demands; there are no private agents who can buy the amount of assets necessary to recapitalize the banking system, even if they knew the value of the assets, because of the sheer size of the banking system. When the banking system is insolvent, many markets stop functioning and this leads to very significant effects on the real economy. This paper makes the case that the ongoing "credit crisis" is a "banking panic."

Gorton and Pennacchi (1990a) argue that the essential function of banking is to create a special kind of debt, debt that is immune to adverse selection by privately informed traders. Also, see Holmström (2008) and Dang, Gorton and Holmström (2009). The leading example of this is demand deposits. More 
generally, this kind of debt is very liquid because its value rarely changes and so it can be traded without fear that some people have secret information about the value of the debt. ${ }^{7}$ If speculators can learn information that is private (only they know it), then they can take advantage of the less informed in trade. This is not a problem if the value of the security is not sensitive to such information. This "informationally-insensitive" debt originally was limited to demand deposits.

But, demand deposits are of no use to large firms, banks, hedge funds, and corporate treasuries, which may need to deposit large amounts of money for a short period of time. These depositors are not willing to deposit, say $\$ 500$ million, in a bank because it cannot be insured. But, in the sale and repurchase ("repo") market it can be "deposited" with a firm and collateralized with bonds, bonds which the depositor receives and that then can used elsewhere (reusing the collateral is called "rehypothecation"). Rehypothecation is somewhat akin to being able to write checks. Further, repo is short-term, like demand deposits, and it can be withdrawn at any time, like demand deposits. The "bank" backs the deposits with bonds as collateral, and often that collateral was securitized products (that is bonds issued by special purpose vehicles to finance portfolios of loans). The demand for collateral grew to include securitized products because of the growing need for collateral in the repo banking system, for collateralizing derivatives positions, and for use for settlement purposes.

Historically, only banks (and, of course, the government) created informationally-insensitive debt, but the demand for such debt has grown. And, now there is a range of securities with different information sensitivities. The notion of "informationally-insensitive" debt corresponds to the institutions that surround debt, as distinct from equity. Equity is very informationally-sensitive. It is traded on centralized exchanges and individual stocks are followed by analysts. Because debt is senior, and because securitized debt is backed by portfolios (see Gorton and Pennacchi (1993a) and Gorton and Souleles (2006)), senior tranches of securitizations are informationally-insensitive, not riskless like demand deposits though. Informationally-insensitive debt does not need extensive institutional infrastructure, like equity. So, for example, the job of rating agencies need not be as in-depth as equity analysts.

The current crisis has its roots in the transformation of the banking system, which involved two important changes. First, derivative securities have grown exponentially in the last twenty-five years, and this has created an enormous demand for collateral, i.e., informationally-insensitive debt. Second, there has been the movement of massive amounts of loans originated by banks into the capital markets in the form of securitization and loan sales. Securitization involves the issuance of bonds ("tranches") that came to be used extensively as collateral in sale and repurchase transactions ("repo"), freeing other categories of assets, mostly treasuries, for use as collateral for derivatives transactions and for use in settlement systems. As discussed above, repo is a form of banking in that it involves the "deposit" of money on call (as repo is short-term, e.g., mostly over night) backed by collateral. The current panic centered on the repo market, which suffered a run when "depositors" required increasing haircuts, due to concerns about the value and liquidity of the collateral should the counterparty "bank" fail. ${ }^{8}$ This

\footnotetext{
${ }^{7}$ To understand that this was an issue historically, one need recall the Free Banking Era; see Gorton (1996, 1999).

${ }^{8}$ Though prior to the run on repo, there was the run on structured investment vehicles (SIVs); see Gorton (2008).
} 
interpretation is developed below and evidence is provided for this viewpoint. Also, see and Gorton and Metrick (2009).

Uninsured bank debt is vulnerable to panic. In the $19^{\text {th }}$ century, before deposit insurance, there were periodic real shocks which caused depositors to be anxious about their banks, described below, in which case they would run to their banks en masse demanding cash. ${ }^{9}$ In the current period, there was a shock in that house prices began to fall. Gorton $(2008,2009)$ argues that this shock to fundamentals was revealed by the $A B X$ index, which is linked to subprime securitization transactions and started trading in January 2006. This is reviewed below. The panic starting in August 2007 involved firms "withdrawing" from other firms by increasing repo haircuts. So, a "banking panic" occurs when "informationallyinsensitive" debt becomes "informationally-sensitive" due to a shock, in this case the shock to subprime mortgage values due to house prices falling.

Understanding that the current crisis is a banking panic is important for thinking about the future of the financial landscape. The reality is that the "shadow banking system" is, in fact, banking. It serves an important function, which should be recognized and protected. In order for that to happen it is useful to ask why the U.S. banking system was panic-free between 1934 and 2007 . The key features of that period provide some guide to thinking about how to recreate a period of quiescence in banking. There are two important features to be discussed. First, bank debt was insured, starting in 1934. And, second, in addition to bank regulation, bank charters were valuable because of subsidies, in the form of limited entry into banking, local deposit monopolies, interest-rate ceilings, and underpriced deposit insurance. In other words, bank regulation not only involved the "stick" of restrictions (reserve requirements, capital requirements, limitations on activities), but also the "carrot," that is, the subsidies. Both the restrictions and the subsidies have varied over time. But, the value of a bank charter eroded in the 1990s with increased competition from nonbanks, and faced only with the stick, the shadow banking system developed out of the regulated banking system. Creating a new Quiet Period requires that "bank" debt be insured, to assure that it is informationally-insensitive, and will require that a valuable charter be recreated for firms that are deemed "banks." A brief proposal along these lines is sketched out as an example.

The paper proceeds as follows. Section 1 briefly reviews the function of "banks," a necessary prelude to understanding what happened. Section 2 reviews the history of banking panics, identifying the crucial characteristics that will again be seen in the current panic. Also, the endogenous response of the banks themselves to panics is briefly discussed. The historical response of banks provides some clues about the problem of panics and the best responses. Section 3 describes the evolution of the shadow banking system. The increase in the demand for collateral, the rise of the repo market, and securitization are discussed. The nexus of these activities constitutes the shadow banking system. The key point is to understand that these activities constitute banking. This is important for thinking about what future regulations should look like. Section 4 briefly describes the panic, starting in 2007. Gorton (2008)

\footnotetext{
${ }^{9}$ E.g., Noyes (1909): "There is a general run of depositors on the banks, with one day (October 24) of almost complete suspension of credit in the great financial markets. There followed the abandonment, by practically all banking institutions in the united States, of the requirements of cash in payment of debt balances between banks at the Clearing House...) (p. 188).
} 
provides much more detail on the panic itself than is explained here. This section draws on, and reviews, the evidence in Gorton (2009) and Gorton and Metrick (2009). Section 5 very briefly reviews this history of bank regulation and the features that allowed for the Quiet Period from 1934 to 2007. Some possible new regulation is very briefly discussed. Section 6 concludes.

\section{Banks and Banking}

During the panic of 1907 a bank run was an almost daily occurrence.

It was a horrible sight and one to make your heart ache with the pathos of it. Hardworking men and women whose deposits in the trust company represented years and years of savings and self-denial being suddenly stripped of all their earnings through no fault of their own. None of them understood what it was about, either.

And hardly ever does the layman understand what it is all about. All he knows is that he put his money in the bank for safe keeping, and it ought to be there when he wants to draw it out. Seward (1924).

In order to "understand what it is all about" -- what a banking panic is about, it is necessary to know what it is that banks do and, in particular, whether their functioning makes the banking system vulnerable to panic. This section provides a brief review.

\section{A. Bank Creation of Informationally-Insensitive Debt}

There is a large academic literature on the functions of banking (see Gorton and Winton (2003) for a review). Most of this academic literature focuses on the bank's asset side of the balance sheet, namely, loans. The basic argument is that bank loans are special because they involve monitoring of the borrower by the bank and the production of private information about the borrower when the loan is made initially. Bank loans have more detailed covenants than bonds so the bank can monitor by enforcing these constraints. Bank loans are usually the first source of external finance for firms, and bond issuance usually comes next, and so is conditional on the firm having a loan (a kind of certification). The implication of these arguments about banking is that bank loans cannot be sold by the bank because then the bank would have no incentive to produce the information in the first place when it made the loan or to monitor the borrower during the life of the loan. Reality contradicts these descriptions of banking because loans are, in fact, sold in significant quantities, as discussed below. This is part of the development of the shadow banking system. So, these academic arguments cannot be the primary reason for the existence of banks, as least today.

On the liability side of the balance sheet, however, banks produce special securities, that is, informationally-insensitive debt that can be used for transactions. Demand deposits are the leading example of this. Their special features are designed to make checks easy to use to conduct transactions. But, the main point about demand deposits is that counterparties accepting checks written to them need not worry about the value of the check, unlike in the Free Banking Era. Many features of checks 
contribute to this. Demand deposits are short term; they essentially have no maturity. Depositors have the right to withdraw their currency at any time. Today, this is because of deposit insurance, the purpose of which is precisely to make it so that no party to the transaction need be concerned about the value of the check. This is the feature of demand deposits that make them a currency. This point was not obvious in the $19^{\text {th }}$ century. For example, Dunbar (1887): "The ease with which we ignore deposits as a part of the currency seems the more remarkable, when we consider that few men in business fail to recognize the true meaning of this form of bank liability; that it is a circulating medium in as true a sense and in the same sense as the bank-note, and that, like the bank-note, it is created by the bank and for the same purposes" (p. 402). Dunbar argues that demand deposits are like currency, which means that it has the basic features of currency - it is informationally-insensitive (though, of course, Dunbar does not say that).

Gorton and Pennacchi (1990a, 1993a) argue that banks create liquidity by producing securities which have this property. Bank debt is designed to be informationally-insensitive, that is, these bonds are not subject to adverse selection when traded because it is not profitable to produce private information to speculate in these bonds. In the extreme, the securities are riskless, like insured demand deposits. Also, see Dang, Gorton and Holmström (2009). "Banking" corresponds to the process of creating this type of debt. Clearly, if the debt is a claim on a diversified portfolio, like a portfolio of bank loans, this is made easier. But, as we will see, this portfolio need not reside at a regulated commercial bank.

In the $19^{\text {th }}$ century before demand deposits were insured, banks went to great lengths to create nearriskless demand deposits, through the use of clearinghouse arrangements, discussed below. But, these arrangements ultimately did not prevent banking panics. The need for informationally-insensitive debt is the logic behind deposit insurance. ${ }^{10}$

But, what about other kinds of debt? More broadly, studies of corporate bond returns and bond yield changes have mainly concluded that investment-grade bonds behave like Treasury bonds, reacting to interest rate movements, while below investment-grade bonds (junk bonds) are more sensitive to stock returns, reacting to information about the firm. ${ }^{11}$ Nevertheless, even investment-grade debt can suffer losses if the issuer defaults. Corporate debt is senior, but it is not (typically) a claim on a diversified portfolio. Senior corporate debt has some features of the kind of debt that is needed for transactions; it is an intermediate case.

A firm, however, may be financed by issuing securities that are claims on the general credit of the corporation, that is, they are backed by the assets of the company (bonds), or the firm can finance itself by segregating specified cash flows and selling claims specifically linked to these specified cash flows. The latter strategy is accomplished by setting up another company, called a Special Purpose Vehicle (SPV) or Special Purpose Entity (SPE), and then selling the specified cash flows to this company; the SPV in turn issues securities into the capital market to finance the purchase of the cash flows from the

\footnotetext{
${ }^{10}$ Deposit insurance is a world-wide phenomenon. See Demirgüc-Kunt, Karacaovali, and Laeven (2005).

${ }^{11}$ Studies of the relation between stock and bond returns at the aggregate level include, e.g., Keim and Stambaugh (1986) and Fama and French $(1989,1993)$, and at the portfolio level they include, and firm level e.g., Blume, Keim, and Patel (1991), and Cornell and Green (1991); at the individual level, see, e.g., Kwan (1996).
} 
company (called the "sponsor"). The sponsor services the cash flows, that is, makes sure that the cash flows are arriving, etc. The SPV is not an operating company in the usual sense. It is more of a robot company in that it is a set of rules. It has no employees or physical location. As we will see, an SPV has some special properties that make it different in other ways as well. The latter process is called securitization.

Securitization involves seniority and large portfolios. The figure below shows the general process of securitization. The figure shows how that the cash flows from assets (loans) created by an originating firm are sold to a special purpose vehicle, which finances this by issuing securities in the capital markets. These securities are based on seniority and are called "tranches." Gorton and Souleles (2006) provide more details. As shown in the figure, securitization involves two conceptual steps. First, underlying cash flows from assets are put into a pool. In other words, the specific assets that are generating the cash flows, usually loans of some sort, are identified and sold (in a specific legal sense) to the SPV. As mentioned above, an important distinguishing feature of asset-backed securities (ABSs) is that they are securities that rely upon the cash flows from a specified pool of assets for payment rather than on the general credit of an issuing corporation. The cash flows emanate from assets originally created by a sponsoring corporation. When they are securitized, the cash flows from these assets are sold into a separate legal entity, the SPV (often its legal structure is a Master Trust) that finances the purchase of the assets through issuance of securities to investors.

The second conceptual step in securitization is that the pool of cash flows sold to the SPV is tranched, that is, securities with different seniorities are designed and issued against the pool. Another way to say this is that the SPV has to have a capital structure, so its liability side must be designed. This is called tranching.

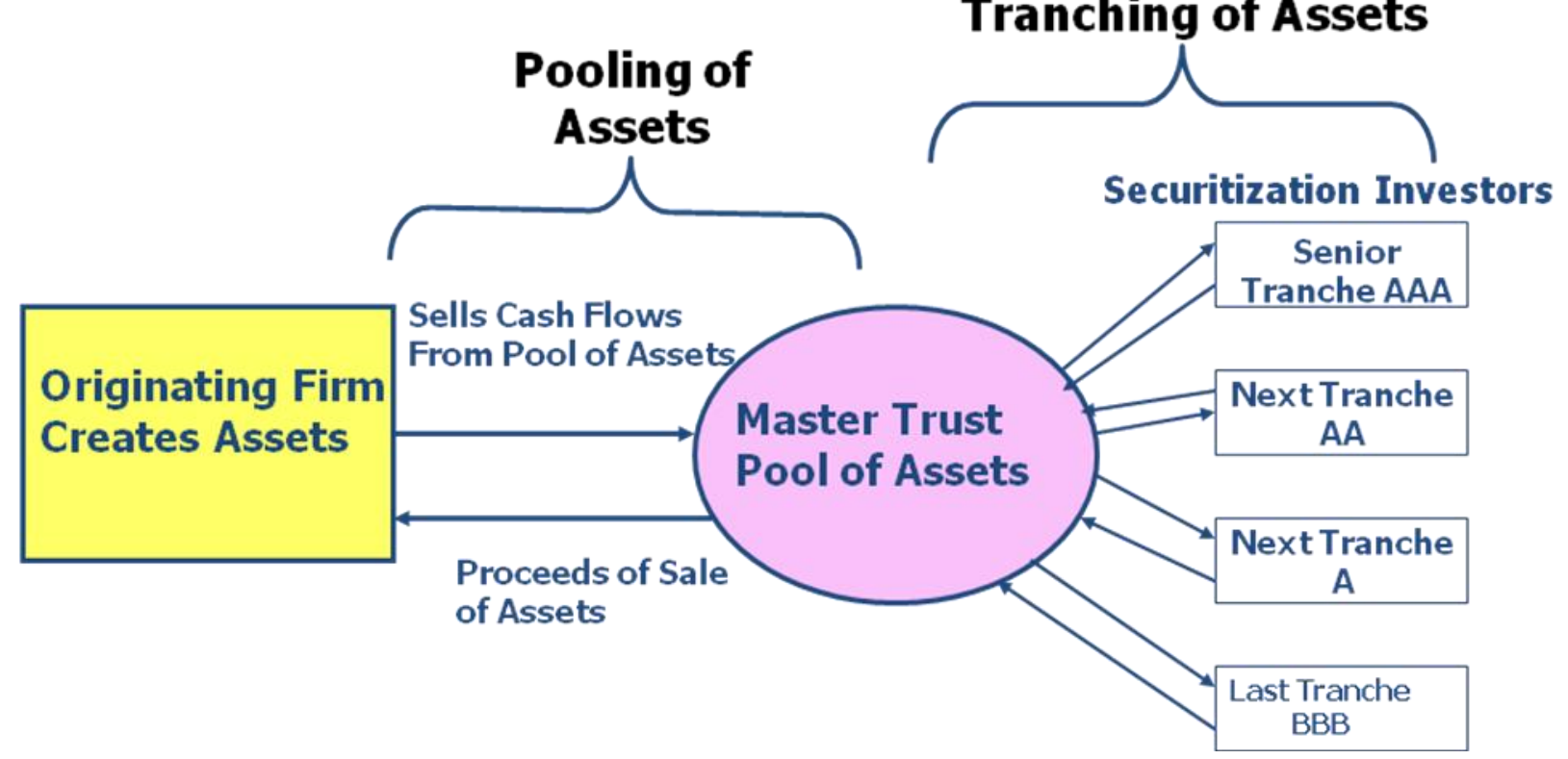


In addition to home mortgages, some other asset classes that have been securitized include:

\begin{tabular}{|l|l|}
\hline \multicolumn{2}{|c|}{ Examples of Securitized Asset Classes } \\
\hline Aircraft leases & Health club receivables \\
\hline Auto loans (prime) & Home equity loans \\
\hline Auto loans (subprime) & Intellectual Property cash flows \\
\hline Auto leases & Insurance receivables \\
\hline B \& C MBS & Motorcycle loans \\
\hline Commercial real estate & Music royalties \\
\hline Computer leases & Mutual Fund receivables \\
\hline Conforming first-lien mortgages & Manufactured housing loans \\
\hline Non-conforming mortgages & Small Business Loans \\
\hline Consumer loans & Stranded utility costs \\
\hline Credit card receivables & Student loans \\
\hline Equipment leases & Trade receivables \\
\hline Equipment loans & Time share loans \\
\hline Franchise loans & Tax liens \\
\hline “Future" receivables & Taxi medallion loans \\
\hline Healthcare receivables & Viatical Settlements \\
\hline
\end{tabular}

Securitized asset classes, e.g., mortgages, credit card receivables, auto loans, may be examples of relatively informationally-insensitive debt, created by the private sector without government insurance. ${ }^{12}$ Several features make securitization debt potentially immune from adverse selection. First, most of the debt is senior and investment-grade. Second, with securitization, the debt is backed by portfolios (see Gorton and Pennacchi (1993a) and Gorton and Souleles (2006)). Third, a by-product of many structured products is that they are complex (as explained by Gorton (2008)). Complexity raises the cost of producing private information. Finally, securitization does not involve traded equity; this is important because there is no information leakage or externalities from the equity market, as with corporate bonds. In summary, senior tranches of securitizations are informationally-insensitive, though not riskless like demand deposits. The most senior tranches of securitization transactions have never experienced defaults.

The outstanding amounts of major asset classes that are securitized are provided below. They are very significant. The non-mortgage securitization issuance has exceeded U.S. corporate bond issuance in recent years. Securitization is far from a trivial amount or an exotic asset class.

Because of the security design, informationally-insensitive debt is surrounded by a different set of trading and related infrastructure and institutions compared to informationally-sensitive asset classes, in particular, equity. Broadly speaking, this debt does not really correspond to the textbook descriptions of

\footnotetext{
${ }^{12}$ Securitization is a world-wide phenomenon. See, for example, Gyntelberg and Remolona (2006), Scatigna and Tovar (2007), Wang (2004),
} 
"efficient markets," a notion that is basically about stock markets. The primary market is over-thecounter, where debt is sold based almost exclusively on its rating. ${ }^{13}$ There is no organized secondary market; instead, the secondary market is organized around dealer banks and depends on intermediation via the repurchase market.

Intuitively, informationally-insensitive debt is debt that no one need devote a lot of resources to investigating. It is exactly designed to avoid that. Just as consumers do not spend a lot of time doing due diligence on the bank that is holding the money of someone buying something from you, the counterpart amount firms and institutional investors will turn out to be collateral, i.e., informationallyinsensitive debt. Think of it as like electricity. Millions of people turn their lights on and off every day without knowing how electricity really works or where it comes from. The idea is for it to work without every consumer having to be an electrician.

A "systemic shock" to the financial system is an event that causes such debt to become informationallysensitive, that is, subject to adverse selection because the shock creates sufficient uncertainty as to make speculation profitable. The details of how that happens are discussed below, but in summary, fear of the resulting lemons market can cause the (inefficient) collapse of trading in debt and a stoppage of new credit being issued. The current crisis was caused by a shock which led to the collapse of debt, because the banking system broadly has evolved to be susceptible to such a shock. This is discussed below. Continuing the analogy from above, when the shock hits, suddenly the electricity stops working. When that happens, an event no one really contemplated, it is too late for everyone to become an electrician. Because the event of losing electricity is so rare, no one understands it, how it could happen, but the solution of everyone becoming an electrician in the future makes no sense.

\section{B. The Demand for Collateral}

Collateral is the currency for firms, that is, firms need to post collateral to mitigate default risk, but also obtain collateral that can be reused or "spent." "Posting collateral" is a way to make good on a promise to pay, as long as the collateral does not lose value while it is posted to the counterparty. We will see that "collateral" is almost synonymous with informationally-insensitive debt, although obviously there are degrees of sensitivity.

The use of collateral has expanded rapidly in the last decade or so. This is due, in large part, to the use of bilateral collateral agreements to address counterparty risk. There is a huge demand for collateral. Financial firms, e.g., dealer banks and commercial banks, have large needs for collateral, and this has grown to an enormous extent. First, collateral is needed in repo markets, where the transaction involves the "deposit" of cash in exchange for a bond as collateral. Second, collateral is also needed in derivatives markets, where it is used to offset counterparty credit risk. Finally, collateral is needed in payment and settlement systems. See, e.g., Bank for International Settlements (BIS) (2001). Probably, the largest demands for collateral come from the repo market, discussed in a subsequent section below. Here the second and third sources of demands for collateral are very briefly discussed.

\footnotetext{
${ }^{13}$ I do not mean to imply that buying on the rating is a bad thing. Rather, because debt is senior and relatively less sensitive to information the level of due diligence is not as intense as with, say equity.
} 
In the last 25 years, the use of derivative securities has grown dramatically. ${ }^{14}$ See the figure below. Derivatives trade under International Swap and Derivative Association (ISDA) master agreements, which often involve a Credit Support Annex (CSA), which specifies the conditions under which parties must post collateral. While counterparty risk is mitigated in a variety of ways, the most important credit enhancement is the posting of collateral in the amount of the current mark-to-market value of the derivative contract. ${ }^{15}$ An ISDA master agreement and the CSA contain a number of provisions which allow each party to protect its position. These provisions are negotiated between the parties when entering into an ISDA agreement. The provisions specify credit support, events of default and termination events, among others things.

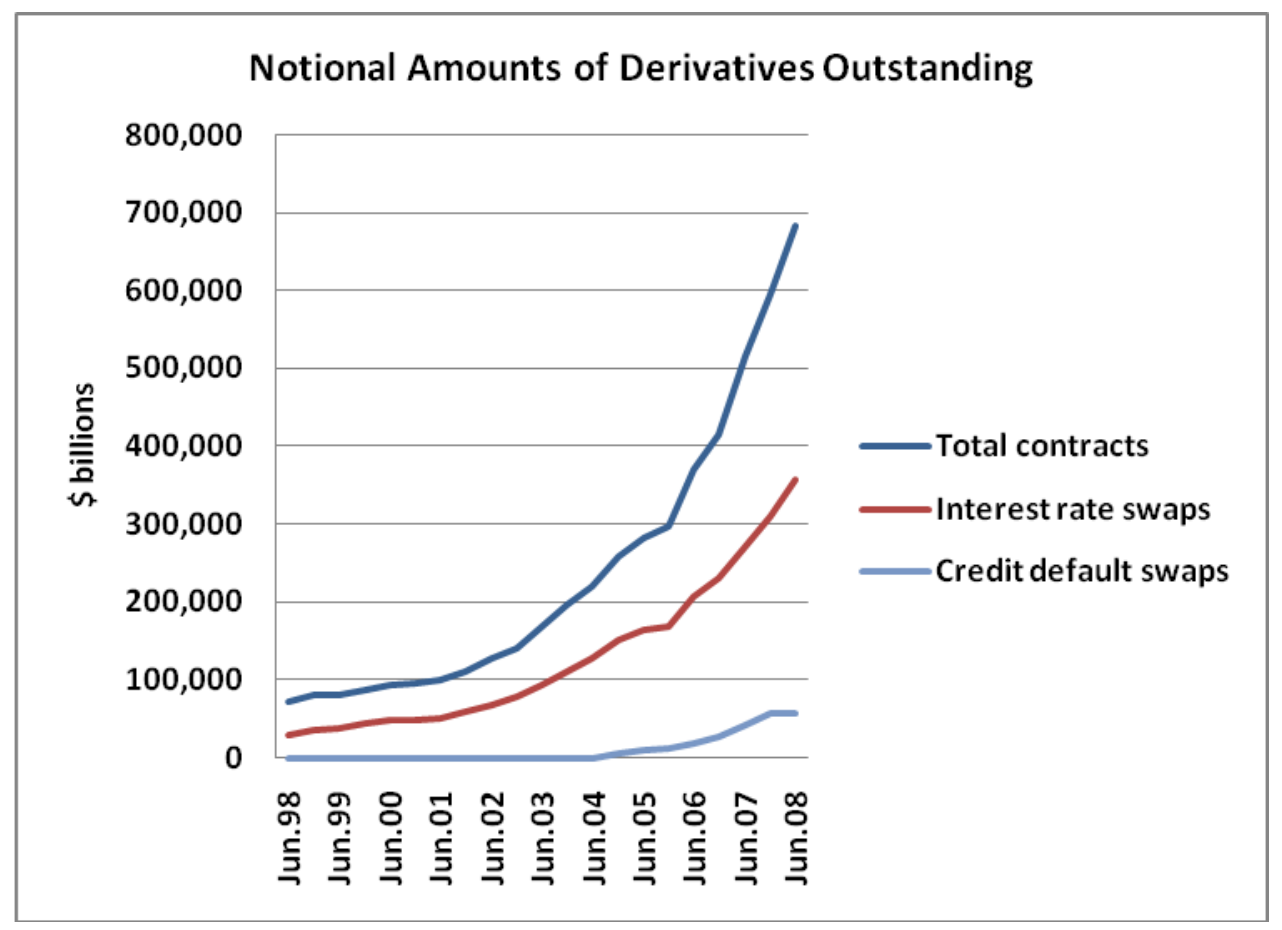

Source: BIS (2008a).

The Credit Support Annex outlines collateral posting requirements, which are among the most significant issues in the original negotiations. The parties may agree to collateralize their exposure to one another only to the extent that such exposure exceeds a certain dollar amount namely, the Threshold. Hedge funds generally must agree to post collateral based on a zero Threshold amount, so that the dealer is fully collateralized, while dealers generally have to agree to post only above a specified amount. Collateral posting is also usually related to various triggers about the credit risk of a party (e.g., ratings triggers) and market-to-market thresholds on the position. For example, Ambac Financial Group

\footnotetext{
${ }^{14}$ Myron Scholes' and Robert Merton's Nobel Prize lectures discuss the history and growth of the derivatives market. See Scholes (1998) and Merton (1998).

${ }^{15}$ Other credit enhancements include ratings triggers that terminate the transaction at market, and third party guarantees. See Litzenberger (1992). Also, see Bliss and Kaufman (2006).
} 
Inc., the bond insurer, lost its AAA credit ratings in 2008 and announced that the downgrades triggered $\$ 776$ million of collateral posting and termination payments at its investment division.

The International Swaps and Derivatives Association (ISDA) (2009) reported that "the amount of collateral used in connection with over-the-counter derivatives transactions grew from $\$ 2.1$ to $\$ 4.0$ trillion during 2008, a growth rate of 86 percent, following 60 percent growth in 2007" (p. 2). According to ISDA (2009):

Collateral coverage continues to grow, both in terms of trade volume subject to collateral agreements and of credit exposure covered by collateral. This reflects a longterm trend toward increased collateral coverage. For all OTC derivatives, 65 percent of trades are subject to collateral agreements, compared with 63 percent last year and 30 percent in 2003. Further, 66 percent of OTC derivative credit exposure is now covered by collateral compared with 65 percent last year and 29 percent in 2003. (p. 2)

Cash is the most important form of collateral for derivatives (see ISDA (2008)). But, that means that that collateral is not available for other purposes. The figure below shows the growth (and the 2009 estimate) in collateral, based on ISDA surveys of its members.

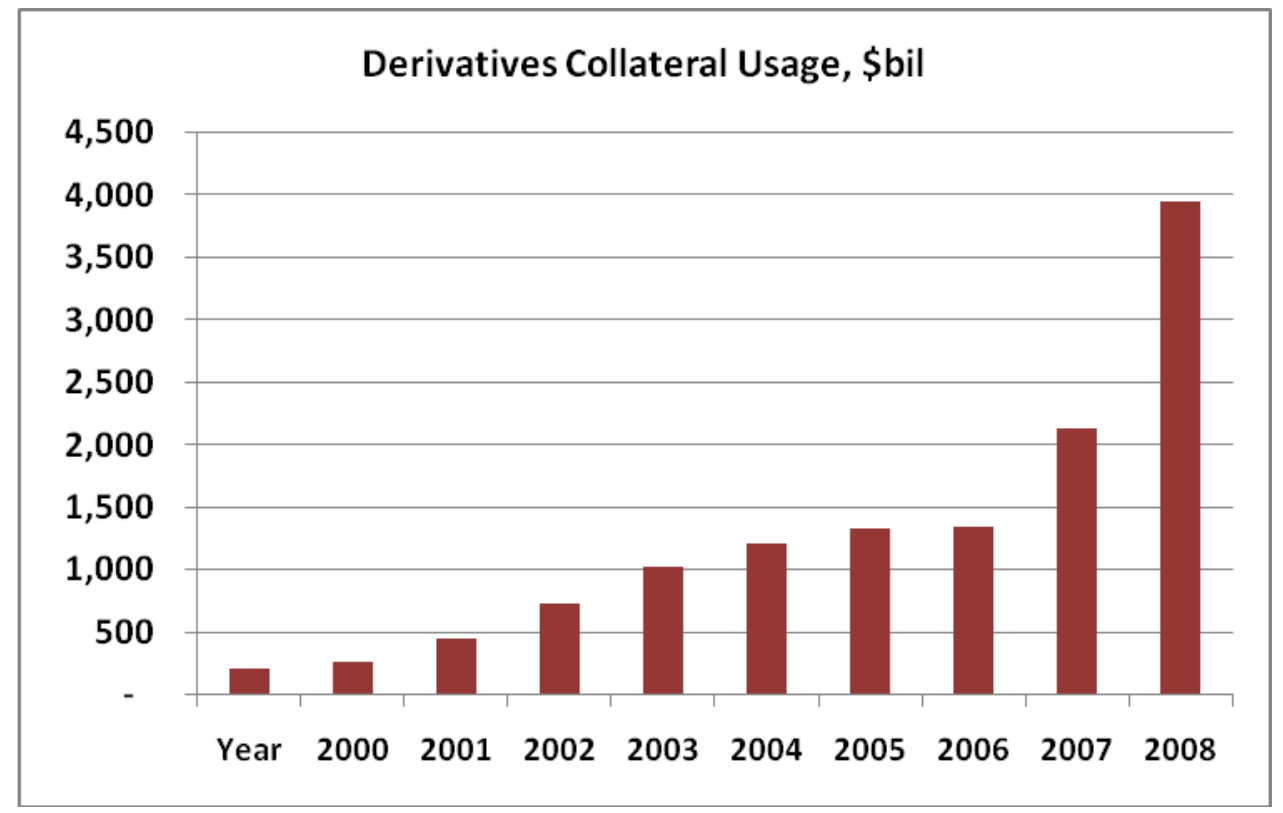

Source: ISDA (2009).

The figure shows the effect of the crisis; collateral usage in 2008 shot up.

Collateral is also needed for purposes of settlement in securities transactions. Delivery versus payment settlement eliminates the settlement risk between parties to a transaction (because the trade and settlement occur simultaneously). Without this, the risk is a possible loss of cash or securities during the time it takes to settle, that is, there is the risk that the promised payment/deliveries do not actually occur. Collateralized intraday credit is one way to mitigate this type of risk. See Zhou (2000) for background. On central bank collateral policies see Chailloux, Gray, and McCaughrin (2008). 
In the last fifteen years or so there has been a shift towards real-time gross settlement (RTGS) systems, usually involving accounts at a central bank. See BIS (2005a, b). "Real time" means that there is no waiting period; the transaction is settled as soon as it is processed. There is no netting of transactions; rather under "gross settlement" the transaction is settled without regard to any other transaction. Under RTGS systems, transactions are only completed if the paying bank has sufficient funds. Central banks usually provide intraday credit, but only on a fully collateralized basis. ${ }^{16}$ According to the Federal Reserve (2006): "In 2005, 64 percent of the approximately 270 depository institutions that paid daylight overdraft fees had assets pledged to the Reserve Banks for discount window purposes" (p. 35683). ${ }^{17}$ The figure below shows the average daylight overdraft amounts, most of which would be collateralized.

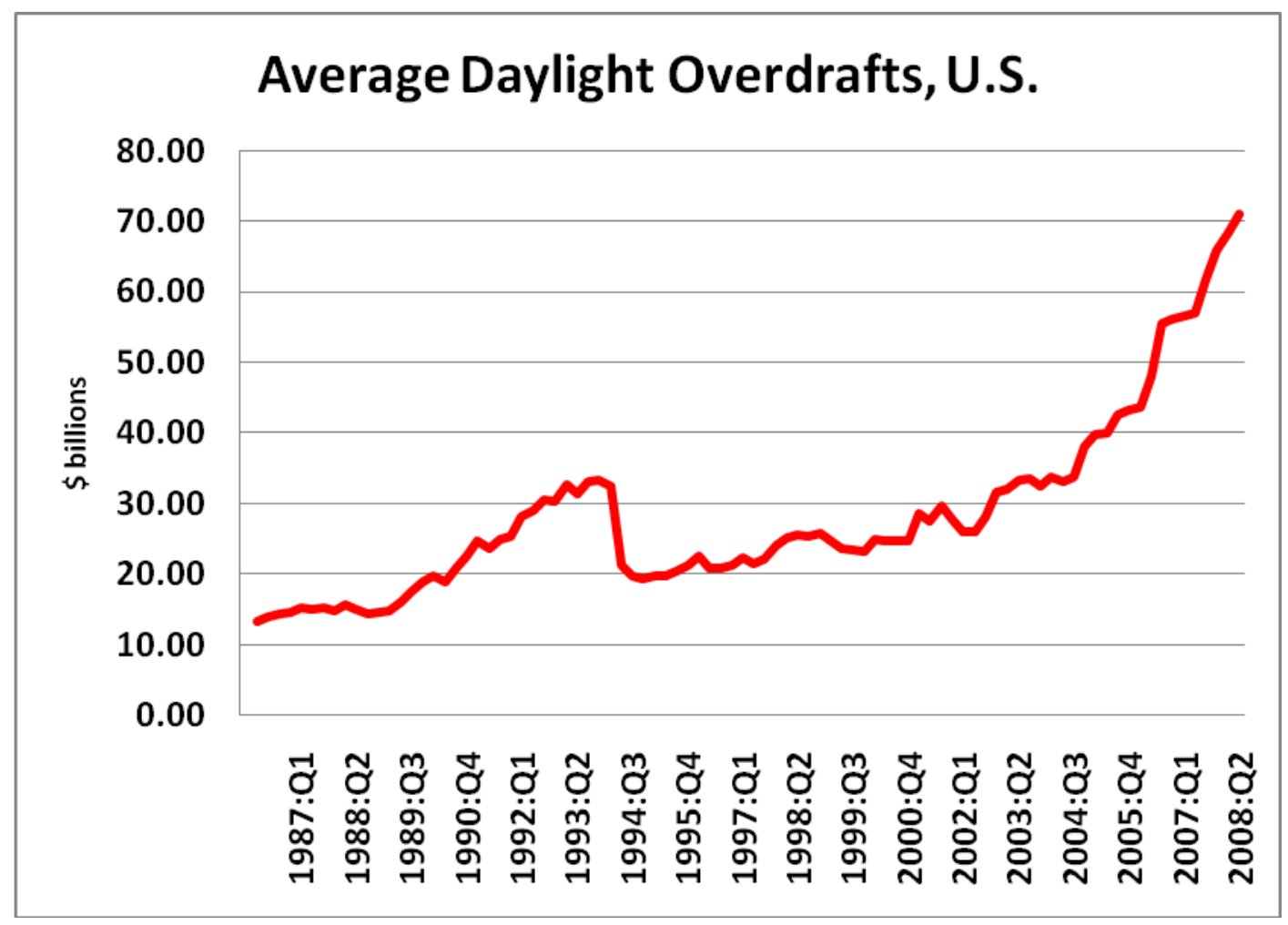

Source: Federal Reserve.

The figure, of course, is only for the U.S., and does not cover the Clearing House Interbank Payments System (CHIPS), or collateral pledged on other futures, options, or stock exchanges. Also, it shows the average, rather than the peak daylight overdrafts. But, the main point is to get a sense of the size and growth of the demand for collateral for settlement purposes. Similar data for other countries is provided by the Bank for International Settlements (2009).

\footnotetext{
${ }^{16} \mathrm{~A}$ bank posts collateral by repoing eligible securities to the central bank.

${ }^{17}$ There is a large academic literature on this topic. E.g., see Angelini (1998), Kahn and Roberds (2001), Furfine and Stehm (1998).
} 


\section{Shadow Banking}

Creation of informationally-insensitive debt is the function of the banking system. In the regulated bank sector this corresponds to insured demand deposits. The characteristics of demand deposits are: (1) demand deposits have no fixed maturity; they can be exchanged for cash at par on demand; (2) they are senior claims; (3) they are claims on a portfolio; (4) they can be used in transactions. This form of debt is created by depository institutions and by money market mutual funds that offer checking.

Shadow banking combines repo with securitization (or other forms of informationally-insensitive debt) to accomplish the same function for firms. Senior tranches of securitized debt and commercial paper (not discussed here) are also quite informationally-insensitive. The shadow banking system, the combination of repo and securitized debt, is a kind of bank, as follows: (1) repo has a short maturity; it is typically overnight and can be withdrawn (not rolled over) on demand; $(2)$ it is senior in that the collateral is senior, but also senior in the sense that there may be a haircut on the collateral (this is discussed below); (3) repo collateral is backed by a portfolio if the collateral is securitization-based debt; (4) the collateral can be used in other transactions, i.e., it can be rehypothecated. Repo is discussed further below.

The shadow banking system is different than depository institutions in that the activity involves the repo market, where depositors and lenders are individually matched; each depositor gets their own collateral. So, the shadow banking system involves a market, the repo market. Securitization enters via the need for collateral. If securitization debt is informationally-insensitive, it can be an input into the repo system of creating a kind of transaction medium, i.e., collateral that can be rehypothecated.

The demand for collateral for purposes of mitigating counterparty risk in derivatives and settlement systems appears large, though the evidence is scanty. Aggregate evidence about the demand for Treasuries is provided by Krishnamurthy and Vissing-Jorgensen (2008) who discuss the demand for Treasury collateral and provide evidence of a "convenience yield" associated with Treasuries, i.e., evidence of their value in use as "cash" rather than just as a store of value. Also, Caballero (2006) discusses the macroeconomic implications of a shortage of collateral.

Prior to the current panic, there was also evidence on the potential scarcity of collateral. For example, the BIS (2001) warned of the problems of a scarcity of collateral, concluding that "Current issuance trends suggest that shortfalls of the stock of preferred collateral may eventually lead to appreciable substitution into collateral having relatively higher issuer and liquidity risk" (p. 2). Also, see Domanski and Neumann (2001). In a "Letter to the European Central Bank," November 28, 2003, from The Bond Market Association:

.... the increasing market focus on collateralisation - a focus encouraged by central banks, by supervisors in encouraging the use of collateral in risk management, by payment and settlement systems in their own endeavours to ensure the integrity of their systems and by market participants' own risk management efforts - means that the demands for collateral within the financial markets are rapidly increasing and can be expected to increase very significantly in the future. 
The topic of demands for collateral reappears below when the repo market is discussed.

\section{Debt and Systemic Events: The Lessons of History}

The causes of crises are so subtle in nature that any attempt to foretell fluctuations in the financial world might well be considered hazardous. No one in the opening months of the year 1860 thought of doubting the continuance of the rising tide of prosperity which had begun to gather strength the year before. And yet the closing months of the year saw such a destruction of trade and credit, and the downfall of so many powerful houses, that the financial situation in New York and, indeed, throughout the United States generally, occasioned deep anxiety to the financiers of the world. Swanson (1908a, p. 65)

Everywhere the banks suddenly found themselves paying out money in response to the demands of frightened depositors, and were in turn forced to draw upon their reserves with other banks. The evidence of lack of confidence in the banks is clear, and points to a serious problem in American banking. ... Seven times during the last century the banks suspended payment in some measure, and there has been a currency premium ... Sprague (1908, p. 363)

Understanding that the current crisis is a banking panic can be made easier by first looking at past panics. While there were banking panics as early as 1792 in the U.S. (see Cowen, Sylla and Wright (2006)), the U.S. National Banking Era, 1863-1913, is a very useful laboratory for studying banking panics because there was no central bank during this period, that is, no government lender-of-last-resort. Also, there was little regulation or deregulation of banks by the federal government (though national banks were chartered by the federal government), but data about national banks was systematically collected. ${ }^{18}$ The period is useful too because there are no peso-type problems with respect to the government (that is, reactions by firms and consumers to the possibility of a government action which then does not occur). Finally, there is a "large" sample, in the sense that panics were a fairly regular event during this period. Gorton (1988) and Calomiris and Gorton (1991) study this period. ${ }^{19}$

What can we learn from the National Banking Era experience of panics? We can observe the central features of panics, and try to understand the nature of the event. Also, we can get clues about the causes of panics by looking at the endogenous response of banks themselves, before there was a government lender-of-last-resort. Lastly, the historical experience of panics provides some clarity as to what a "systemic" event is.

\footnotetext{
${ }^{18}$ There were banking panics in the U.S. prior to the National Banking Era, but they are harder to study because banks were state-chartered then and data is harder to collect. See, e.g., Rezneck (1933), McGrane (1924), and Davis (2001).

${ }^{19}$ Other citations to the empirical work on panics in the U.S. are given in Gorton (2008), but those are not exhaustive.
} 


\section{A. U.S. National Banking Era Panics, 1864-1913}

The National Banking Act was passed in 1863, creating a system of national banks and a uniform national currency. The Act also established the Office of the Comptroller of the Currency. The table below lists the banking panics that occurred in the U.S. during the National Banking Era.

\begin{tabular}{|c|c|c|c|c|c|}
\hline \multicolumn{6}{|c|}{ U.S. National Banking Era Panics } \\
\hline $\begin{array}{c}\text { NBER Business Cycle } \\
\text { Dates } \\
\text { Peak - Trough }\end{array}$ & Panic Date & $\% \Delta(C / D)$ & $\% \Delta$ (Pig Iron) & $\begin{array}{l}\text { Loss per } \\
\text { Deposit \$ }\end{array}$ & $\begin{array}{c}\% \text { and \# of } \\
\text { U.S. National } \\
\text { Bank Failures }\end{array}$ \\
\hline Oct. 1873 - Mar. 1879 & Sep. 1873 & 14.53 & -51.0 & 0.021 & $2.8(56)$ \\
\hline Mar. 1882 - May 1885 & Jun. 1884 & 8.8 & -14.0 & 0.008 & $0.9(10)$ \\
\hline Mar. 1887 - Apr. 1888 & No Panic & 3.0 & -9.0 & 0.005 & $0.4(12)$ \\
\hline Jul. 1890 - May 1891 & Nov. 1890 & 9.0 & -34.0 & 0.001 & $0.4(14)$ \\
\hline Jan. 1893 - Jun. 1894 & May 1893 & 16.0 & -29.0 & 0.017 & $1.9(74)$ \\
\hline Dec. 1895 - Jun. 1897 & Oct. 1896 & 14.3 & -4.0 & 0.012 & $1.6(60)$ \\
\hline Jun. 1899 - Dec. 1900 & No Panic & 2.78 & -6.7 & 0.001 & $0.3(12)$ \\
\hline Sep. 1902 - Aug. 1904 & No Panic & -4.13 & -8.7 & 0.001 & $0.6(28)$ \\
\hline May 1907 - Jun. 1908 & Oct. 1907 & 11.45 & -46.5 & 0.001 & $0.3(20)$ \\
\hline Jan. 1910 - Jan. 1912 & No Panic & -2.64 & -21.7 & 0.0002 & $0.1(10)$ \\
\hline Jan. 1913 - Dec. 1914 & Aug. 1914 & 10.39 & -47.1 & 0.001 & $0.4(28)$ \\
\hline
\end{tabular}

Source: Gorton (1988).

The first two columns show the National Bureau of Economic Research (NBER) business cycle dates and the date of the panic. The NBER dates were determined by Burns and Mitchell (1946). There has been subsequent work based on new data that has made some of the dates slightly suspect. ${ }^{20}$ See Miron and Romer (1990), Romer (1994), and Davis (2006, 2004). The panic dates are based on when clearinghouses issued loan certificates, discussed below, and on contemporary sources, stating when depositors were observed running on banks. This usually started in large cities and spread across the country. ${ }^{21}$ Looking at the panic dates it is notable that they occur very near the peak of the business cycle in most cases. In fact, based on the discussion below, the panic date may be a better indicator of the business cycle peak date.

\footnotetext{
${ }^{20}$ Fels (1951), speaking of the panic of 1893, wrote: “"...there are many reasons for not accepting the Bureau's dates in blind faith. Not the least of which is the scarcity of monthly data for the 1870 's" (p. 336).

${ }^{21}$ Miron and Romer (1990): “. . . there are some important differences between our index and various alternatives. These differences are especially noticeable around the dates of major financial panics. For example, following the banking panic of May 1884, our index shows a much more immediate fall in production than does the pig iron series that has been used in other analyses. This is also the case around the panic of October 1907. The new index, like the Babson and Persons indexes, turns down perceptibly before the panic, whereas the frequently used pig iron series does not turn down until November 1907. These differences in the timing of real output movements around financial panics could have large effects in studies that seek to identify the direction of causation between panics and recessions" (p. 332).
} 
The panics are associated with recessions, and some with very serious recessions. See Grossman (1993). The panics of 1873 and 1907 are notable in this regard. ${ }^{22}$ The declines in real economic activity, as proxied for by the change in pig iron production, and the length of the recession are very significant.

The table also shows the percentage change in the currency-deposits ratio, the percentage change in pig iron production, the loss per dollar of deposits and the percentage and number of National Bank failures. These variables are measured from panic date to trough date. Pig iron production is a common measure of monthly economic activity during the National Banking Era. Looking at the change in pig iron production, it is clear that panics are associated with very serious subsequent recessions. By this measure, the three worst panics, 1873, 1907 and 1914, were followed by declines of 51 percent, 46 percent, and 47 percent, respectively. The currency-deposit ratio also rises, reflecting withdrawals at banks, but this is tempered by the suspension of convertibility, which was the first act of banks faced with a generalized panic. On suspension, see Gorton (1985a).

The final two columns are remarkable in showing that the losses per deposit dollar and the percentage of National banks failing were quite low. The reasons for this have to do with the response of private bank clearinghouses to panics, discussed below.

These historical banking panics had four important characteristics. First, the banking system is insolvent. Depositors run to their banks en masse seeking to withdraw money from checking and savings accounts. ${ }^{23}$ The banking system cannot honor these demands because the money has been lent out. The loans are illiquid, that is, there is no one capable of buying a sufficient amount of assets to recapitalize the banking system, and so banks cannot honor depositor demands. The evidence for the insolvency of the banking system during a panic is discussed below, when clearinghouse loan certificates are discussed.

Second, because of the hoarding of cash and despite the efforts of bank clearinghouses, discussed below, there was a shortage of transaction mediums, repeatedly described by contemporary observers as a "currency famine." Transactions were disrupted because of a lack of means of payment. For example, firms could not meet payrolls because employees would not accept bank checks. Checks could not be used at stores because they were not accepted. Certified checks exchanged at deep discounts. And this currency famine occurred despite the issuance of clearinghouse loan certificates (discussed below), as well as many other kinds of money substitutes. See, e.g., Andrew (1908b).

Thirdly, the hoarding of cash led to a currency premium. That is, currency sold at a premium to certified checks, and sometimes a premium was paid for a large amount of cash (by a country bank to a city bank, for example). Dwyer and Gilbert (1989) contain figures showing the evolution of the currency premiums during the panics of 1893 and 1907. Also, see Andrew (1908a), Sprague (1910), Noyes (1894). ${ }^{24}$

\footnotetext{
${ }^{22}$ On the Panic of 1893 se, e.g., Fels (1951), Noyes (1894), Rezneck (1953), and Stevens (1894); on the Panic of 1907 see, e.g., Sprague (1908) and Moen and Tallman (1990). Also, see Calomiris and Gorton (1991).

${ }^{23}$ Country banks also withdrew money on deposit with city banks, reminiscent of today's crisis.

${ }^{24}$ Friedman and Schwartz (1971) discuss the currency premium during the Great Depression, p. 110.
} 
The final point concerns the timing of the panics and was noted above. Panics occurred at business cycle peaks. The observation about timing is related to explaining the cause of panics. Gorton (1988) analyzes the causes of panics empirically, estimating a model of a representative agent facing a cash-inadvance constraint. The agent saves by depositing in a risky bank. This agent cares about the intertemporal marginal rate of substitution, so the pricing kernel weights the expected returns on the demand deposits, in determining the currency-deposit ratio. In other words, the agent cares about possible losses on his savings should the bank fail and, to the extent that these losses are to come in bad times, the agent will hold more currency relative to deposits. Bank losses that come in bad times are particularly bad because consumption is lower in ad times. Just when the agent is worse off in terms of consumption, the bank might fail. So, in a recession income and consumption decline and banks tend to fail, because their borrowers also tend to fail. If the agent anticipates this, then he will withdraw from the bank to avoid losses on his bank savings occurring during the recession.

Gorton (1988) estimates this model and, in particular, asks what information arrives that causes the agent to forecast the coincidence of consumption being low and banks failing. The answer is that a leading indicator of recession, the cyclical component of the liabilities of failed businesses spikes, indicating that a recession is coming and, having received this information, agents in the economy rush to their banks to withdraw money, in a panic. During the National Banking Era, every time this leading indicator was greater than 0.83 , there was a panic. There are no cases of a panic when the indicator is not higher than this threshold.

The information that depositors received was aggregate information, not specific information about individual banks. People knew that a recession was coming and that in a recession some banks were likely to fail, but no one knew which banks. So, it was rational to take the precautionary action of withdrawing from all banks. The shock threshold was literally large enough to cause a panic.

This is related to the function of banks, discussed above. Banks try to produce securities that are useful for transacting, namely bank debt - demand deposits. But, in a panic, people lose confidence in the value of bank debt. Bank debt that was previously viewed as "safe" becomes viewed with suspicion. In this context, "safe" means two, related, things. First, the value of the bank debt does not change much, a ten dollar check is pretty much always worth ten dollars. And, second, because of this it is not susceptible to adverse selection when it is used in transactions (traded in markets). That is, it does not pay anyone to produce private information about the value of the bank debt and speculate on that information.

A panic is a situation where a shock occurs that is large enough for bank debt to become informationally-sensitive. It loses its most important feature and so agents do not want it anymore; they want an asset which is surely informationally-insensitive-cash. When that happens, the banking system cannot honor the demands and is insolvent.

How did banks respond to panics during the National Banking Era? Their response will give us clues as to the causes and remedies for panics. 


\section{B. The Private Bank Clearinghouse Response to Panics}

During the National Banking Era there was no central bank to act as a lender-of-last-resort. So, what happened during a panic? During the $19^{\text {th }}$ century the banks themselves developed increasingly sophisticated ways to respond to panics. The response was centered on private bank clearinghouses. Originally organized to be an efficient way to clear checks, these coalitions or clubs of banks evolved into much more. Towards the end of the National Banking Era the clearinghouse response was essentially as follows. ${ }^{25}$

In response to a panic, banks would jointly suspend convertibility of deposits into currency. Coincident with this, clearinghouse member banks joined together to form a new entity overseen by the Clearinghouse Committee. As Swanson (1908b, p. 221) put it, describing the crisis of 1860, there was "the virtual fusion of the fifty banks of New York into one central bank" (p. 221). The clearinghouse would also cease the publication of individual bank accounting information (which banks were normally required by the clearinghouse to publish in the newspapers) and would instead only publish the aggregate information of all the members. Finally, banks issued loan certificates, which were first used to replace currency in the clearing process, starting with the Panic of 1857. But, in the Panics of 1893 and 1907 the clearinghouse issued new money called clearinghouse loan certificates directly to the public in small denominations. See Gorton (1985b). These were liabilities of the clearinghouse members jointly and served the purpose of providing a kind of deposit insurance. The clearinghouse loan certificate was a remarkable innovation, resulting from individual private banks finding a way to essentially become a single institution, responsible for each other's obligations during a panic and issuing a hand-to-hand currency.

The table below shows the amounts of clearinghouse loan certificates issued by the New York City Clearinghouse Association. The details of how the clearinghouse required collateral and set rates on the collateral are provided in Gorton (1985b) and Canon (1910). Other cities typically followed New York and also issued certificates. Sprague (1903): "The position of the more important New York banks is entirely analogous to that of the great central reserve banks of Europe, such as the Bank of England and the Bank of France. Any unusual demand for actual cash . . . is certain sooner or later to bring about a withdrawal of money from the New York national banks" (p. 34).

\footnotetext{
${ }^{25}$ The information about clearinghouses is drawn from Gorton (1985b) and Gorton and Mullineaux (1987). Also, see Cannon (1910) and Gorton and Huang (2006).
} 


\begin{tabular}{|lcccc|}
\hline \multicolumn{2}{|l}{ Clearinghouse Loan Certificates Issued by the New York Clearinghouse (\$millions) } \\
\hline Year & Date First Issued & $\begin{array}{c}\text { Months until } \\
\text { Redeemed }\end{array}$ & $\begin{array}{c}\text { Maximum } \\
\text { Amount Created }\end{array}$ & Bank Deposits \\
\hline $\mathbf{1 8 6 0}$ & November 23 & 3.5 & $\mathbf{\$} 6.9$ & $\$ 99.6$ \\
\hline $\mathbf{1 8 6 1}$ & September 19 & 7.25 & 22 & 99.3 \\
\hline $\mathbf{1 8 6 3}$ & November 6 & 2.75 & 9.6 & 159.5 \\
\hline $\mathbf{1 8 6 4}$ & March 7 & 3.25 & 16.4 & 168.0 \\
\hline $\mathbf{1 8 7 3}$ & September 22 & 3.75 & 22.4 & 174.8 \\
\hline $\mathbf{1 8 8 4}$ & May 15 & 4.25 & 21.9 & 317.2 \\
\hline $\mathbf{1 8 9 0}$ & November 12 & 2.75 & 15.2 & 386.5 \\
\hline $\mathbf{1 8 9 3}$ & June 21 & 4.66 & 38.3 & 398.0 \\
\hline $\mathbf{1 9 0 7}$ & October 26 & 5 & 88.4 & 1023.7 \\
\hline $\mathbf{1 9 1 4}$ & August 3 & 4 & 109.2 & -- \\
\hline
\end{tabular}

Sources: Report of the Comptroller of the Currency, 1907, p. 63; Dwyer and Gilbert (1989); Swanson (1908b).

In 1893 and 1907, depositors, unsure of the risk of their own single bank failing, were not able to obtain cash, but received instead a claim on the clearinghouse member bank jointly. Thus, depositors were insured against their own bank failing, but were not insured against the entire clearinghouse failing. The issuance of clearinghouse loan certificates was not insignificant. In the Panic of 1893 about $\$ 100$ million of hand-to--hand currency was issued (2.5 percent of the money stock). During the panic of 1907 about $\$ 500$ million was issued, which was about 4.5 percent of the money stock. See Gorton (1985b) and Dwyer and Gilbert (1989).

In 1893 and 1907 when clearinghouse loan certificates were issued to the public in small denominations, they traded initially at a discount to par, reflecting the belief that there was some chance that the clearinghouse was insolvent. This is evidence of the "insolvency" of the banks in the clearinghouse, essentially the banking system since this occurred nationwide. Over time the discount was reduced, and suspension was lifted afterwards. Following the return to normalcy the clearinghouse might announce the insolvency of a member bank.

The clearinghouse response did not prevent panics. But, clearinghouse actions prevented wholesale liquidation of the banking system in the face of system insolvency. Still, there were still real effects from the crisis. The most important real effect, based on the writings of contemporaries, concerned the disruption of transactions due to a shortage of cash. How much this contributed to the recession is not known.

Clearinghouse actions in response to panics offer clues to the causes of a panic. First, it is notable, and somewhat counterintuitive, that the clearinghouse, after suspending convertibility, would suspend the release of bank-specific information. This is completely contrary to an "efficient markets" view of the world. The logic of the clearinghouse response to a panic was to form a single institution, the coalition, and only information about this entity was relevant. See Gorton and Huang (2006). Second, clearinghouse loan certificates were issued, financial claims on the coalition of banks. Essentially what happened was that the clearinghouse tried to make bank liabilities more informationally-insensitive by 
replacing bank-specific deposits with certificates that were claims on the whole coalition. ${ }^{26}$ This meant that bank-specific information was not relevant. Clearinghouses attempted to provide a kind of deposit insurance, by issuing loan certificates in times of panic.

The clearinghouse response to panics was exactly the opposite of the view that it is important to "markto-market" the assets of the banking system. The clearinghouse decisively recognized that the assets could not be sold and that such "marking" was meaningless. The effects of marking-to-market are studied by Adrian and Shin (2009a, b). The clearinghouse was an incentive-compatible mechanism for agreeing on when suspension should occur, including the change in the information regime. This is an important clue for understanding panics.

The clearinghouse system continued to evolve until the Federal Reserve System came into being. For example, by the early part of the $20^{\text {th }}$ century, the clearinghouse had its own bank examiners, starting in Chicago in 1906 and "introduced in St. Paul and Minneapolis in 1907,Kansas City, Los Angeles, and San Francisco in 1908; St. Joseph and Philadelphia in 1909, Milwaukee, Oklahoma City, and Nashville in 1910; Portland (Ore.), Cleveland, Louisville, Cincinnati, and New York in 1911, and Columbus, New Orleans, and Muskogee in 1912" New York Times, September 28, 1913 (Society, Theaters, Schools Real Estate, Financial, Business section, p. X15). Given the mutual obligations adopted by clearinghouse members, banks thought "they were entitled to know the conditions of each member bank" NYT, September 28, 1913. "The examiner is not burdened with rules or instructions. He is interested principally in determining the solvency and healthfulness of an institution and the character of its management" NYT, September 28, 1913.

How successful was the clearinghouse in dealing with panics? Obviously, clearinghouses did not prevent panics. But, they did prevent wholesale liquidation of banks due to insolvency caused by the runs. Banks were not forced to sell assets. The table below shows the causes of bank failures based on the Comptroller of the Currency's classification of failures, categorized into three groups by Thomas (1935). The numbers in the table are the ratio of occurrences of each cause to the total occurrences of all causes, i.e., each number is a percentage. The data are expressed as a percentage because the number of banks changes over this long period. The data show that the cause of bank failures during normal times is poor management and illegal activity. During panics or recessions, more banks fail, but as a percentage of the total failures the causes of failure are still largely poor management and illegal activity. During the Panic of 1873 and the aftermath, the two categories are almost equally likely. During the Panic of 1907, mostly trusts failed, not national banks. During the Panic of 1914, 88 percent of the failures were poor management and illegal activity. Thomas (1935): "One may conclude . . that a prevention of operation of these 'internal causes' consisting of incompetent management, fraud, and violation of established banking law would be far in abolishing bank failure even in bad times" (p. 299).

\footnotetext{
${ }^{26}$ The Panic of 1914 involved the government issuing a kind of money that had been authorized under the AldrichVreeland Act. See Sprague (1915) and Silber (2007a, b). When the Federal Reserve System came into existence these features of the Aldrich-Vreeland Act were not incorporated. In this sense, the panics of the Great Depression were very special. See Gorton (1988).
} 


\begin{tabular}{|lcccc|}
\hline \multicolumn{1}{|c|}{ Years } & $\begin{array}{c}\text { Poor } \\
\text { Management } \\
\text { (1) }\end{array}$ & $\begin{array}{c}\text { Fraud and } \\
\text { Violation of the } \\
\text { Law } \\
(\mathbf{2})\end{array}$ & $\begin{array}{c}\text { All Internal Bank } \\
\text { Causes } \\
\text { (1) Plus (2) }\end{array}$ & $\begin{array}{c}\text { Depression and } \\
\text { Depreciation of } \\
\text { Assets }\end{array}$ \\
\hline $\mathbf{1 8 6 5 - 1 8 7 2}$ & $47 \%$ & $32 \%$ & 79 & 20 \\
\hline $\mathbf{1 8 7 3 - 1 8 7 9}$ Panic & 26 & 23 & 49 & 50 \\
\hline $\mathbf{1 8 8 0 - 1 8 8 9}$ & 21 & 41 & 62 & 37 \\
\hline $\mathbf{1 8 9 0 - 1 9 0 0}$ Panic & 31 & 29 & 60 & 38 \\
\hline $\mathbf{1 9 0 1 - 1 9 0 5}$ & 21 & 48 & 69 & 30 \\
\hline $\mathbf{1 9 0 6 - 1 9 0 8}$ Panic & 25 & 48 & 73 & 26 \\
\hline $\mathbf{1 9 0 9 - 1 9 1 3}$ & 20 & 55 & 75 & 25 \\
\hline $\mathbf{1 9 1 4 - 1 9 2 0}$ Panic & 25 & 63 & 88 & 12 \\
\hline $\mathbf{1 9 2 1 - 1 9 2 2}$ Recession & 23 & 18 & 41 & 60 \\
\hline $\begin{array}{l}\text { 1923-1929 } \\
\text { West of Miss. }\end{array}$ & 31 & 9 & 40 & 41 \\
\hline $\begin{array}{l}\text { 1923-1929 } \\
\text { East of Miss. }\end{array}$ & 32 & 26 & 58 & 47 \\
\hline 1930-1931 Recession & 51 & 1 & 52 & \\
\hline
\end{tabular}

Source: Thomas (1935), based on Annual Reports of the Comptroller of the Currency. The data concern national banks placed in the hands of receivers.

\section{Summary}

What can we conclude about the National Banking Era panics?

- Banking panics during the National Banking Era were caused by shocks, information about the real economy that came at business cycle peaks. The information indicated that a recession was imminent, a time when consumers would want to dissave to smooth consumption (i.e., draw down their savings at banks to try to maintain their consumption level). But, recession is a time when their bank is more likely to fail. So, as a precaution they sought to withdraw cash. $^{27}$

- Depositors were confused about which banks were really at risk and consequently ran all banks. How do we know depositors were confused about which banks were at risk? One indication was that the clearinghouse prohibited individual bank information from being published. The idea was that weak banks were not to be exposed. In fact, ex post, few banks failed.

- The response of clearinghouses, issuing loan certificates to replace cash in the clearing process was a method of conserving cash collateral. When the certificates were handed out directly to the public to honor withdrawals, their design of being claims on the entire clearinghouse are consistent with the motivation of creating informationally-insensitive claims.

\footnotetext{
${ }^{27}$ As discussed in Calomiris and Gorton (1991), banking panics only occurred in banking systems characterized by many smaller banks. Also see Gorton and Huang (2006). Banking systems with a few large banks, e.g., Canada, have no experience of panics.
} 
- A banking panic is a systemic event because the banking system as a whole is insolvent. How do we know that the banking system was insolvent? For the panics of 1893 and 1907 when clearinghouse loan certificates were issued directly to depositors, these financial claims traded at a discount to par, reflecting the expected losses on the coalition of banks.

- Did asset prices fall during these panics? Bank asset prices did not fall because there was no need to sell assets. Banks suspended convertibility, i.e., failed to honor their deposit contracts. Consequently, they did not have to sell loans and mortgages, and there was no market anyway.

- In a panic cash is hoarded and there is a shortage of transactions mediums.

The response of private bank clearinghouses was to suspend convertibility, cut-off the flow of bankspecific information, and to issue private money, clearinghouse loan certificates, that were the joint liability of clearinghouse member banks. This did not prevent panics from occurring. But, it was very successful in preventing massive liquidations of banks.

\section{The Evolution of Banking in the last 25 Years - The Rise of "Shadow" Banking}

Actually, throughout these decades [1882-1910] National Banks continuously tried to expand the scope of their activities beyond the traditional commercial banking ... some banks organized bond departments ... the financing of stock speculation on call ... the profits of some of the biggest banks were tremendous, especially those which entered investment banking. Redlich (1947, p. 180, 183).

Banking has always been in a constant process of change. ${ }^{28}$ The evolution of banking in the last 25 years is due to a number of forces, but the main point here is that the shadow banking system that emerged is a real banking system. Above, the shadow banking system was defined as a combination of the repo market and the necessary collateral, including securitization debt. This section describes the development of the shadow banking system and explains a bit more about how it operates to provide banking services.

\section{A. The Development of the Shadow Banking System}

The banking system evolved over the last twenty-five years in a number of fundamental ways. This evolution was a product of increased competition from nonbanks, decreased regulation, and innovation in financial products. Increased competition came from money market mutual funds, on the liability side of the bank balance sheet, and from junk bonds, on the asset side of the bank balance sheet. ${ }^{29}$ In the early 1970s interest rate ceilings on deposits were phased out; banks were allowed to engage in a

\footnotetext{
${ }^{28}$ The literature on financial innovation includes Miller (1986), Tufano (2004), Merton (1992), and Lerner (2006).

${ }^{29}$ On money market mutual funds, see, e.g., Gorton and Pennacchi (1993b). On junk bonds competing with bank loans, see Benveniste, Singh, and Wilhelm (1993) and Molyneux and Shamroukh (1996).
} 
variety of other financial activities; restrictions on geographic scope were eliminated. ${ }^{30}$ Innovation came in many forms. Derivative securities became an important product line (e.g., see Gorton and Rosen (1995)). Loans became more liquid; they could be sold in secondary markets (see Gorton and Pennacchi $(1989,1995))$. And securitization allowed portfolios of loans to be sold into the capital markets. For our purposes securitization is the most important development. Later, loan sales are briefly discussed.

As discussed above, securitization is a form of off-balance sheet banking. Loans originated by banks are sold to a special purpose vehicle (SPV) (a legal entity) which finances the purchase of the portfolio of loans by issuing investment-grade securities in the capital markets. The SPV is robotic in the sense that no one works there and there is no physical location for the SPV. Servicing the loans is outsourced and the cash flow from the loans is allocated according to pre-specified rules. Importantly, SPVs are bankruptcy remote, meaning that the failure of the originator of loans is not relevant to the investors in the securitization bonds, called "tranches." The loans that were sold to the SPV cannot be clawed-back by an originator that is in bankruptcy. Also, the SPV itself cannot go bankrupt. If the cash flow from the loan portfolio that constitutes the assets of the SPV is insufficient for make the payments on the tranches, then early amortization is triggered. This is not an event of default. See Gorton and Souleles (2006) for more details.

The table below shows issuance of various asset classes, over the period 1996-2008. The two relevant columns with regard to securitization are the columns labeled "mortgage-related" and the column labeled "asset-backed."

The column labeled "Mortgage-Related" includes all securitized mortgages, both privately securitized product but also securitizations by the housing government-sponsored entities. By issuance, mortgagerelated bonds are the largest category traded debt in the U.S. Also, of particular note, is the fact that non-mortgage asset-backed securities ("asset-backed") exceeded the issuance of U.S. corporate debt in 2004-2006. These securities are the obligations of SPVs holding a variety of loan types, such as, credit card receivables, auto loans, student loans, and so on. Securitization is a very significant form of financing.

Securitization is banking in the sense that the SPVs hold loans and finance these loans with high-grade debt, debt which is largely informationally-insensitive. This debt is investment-grade and has an information advantage over equivalently rated corporate debt. Speculation can occur in corporate bonds based on information from the company's stock. Capital structure arbitrage, which involves taking long and short positions in different instruments of a company's capital structure; see Yu (2005). Implementation of this strategy involves comparing credit derivative swap spreads to the firm's equity price with a structural model.

${ }^{30}$ Strahan (2003) argues that deregulation was "followed by better performance of the real economy. State economies grew faster and had higher rates of new business formation after this deregulation. At the same time macroeconomic stability improved" (p. 111). 


\begin{tabular}{|c|c|c|c|c|c|c|c|}
\hline \multicolumn{8}{|c|}{ Issuance of Various Types of Securities in the U.S., 1996-2008 (\$\$bil.) } \\
\hline & Municipal & Treasury $^{1}$ & $\begin{array}{l}\text { Mortgage- } \\
\text { Related }^{2}\end{array}$ & $\begin{array}{l}\text { Corporate } \\
\text { Debt }^{3}\end{array}$ & $\begin{array}{c}\text { Federal } \\
\text { Agency } \\
\text { Securities }\end{array}$ & $\begin{array}{l}\text { Asset- } \\
\text { Backed }\end{array}$ & Total \\
\hline 1996 & 185.2 & 612.4 & 492.6 & 343.7 & 277.9 & 168.4 & $2,080.2$ \\
\hline 1997 & 220.7 & 540.0 & 604.4 & 466.0 & 323.1 & 223.1 & $2,377.3$ \\
\hline 1998 & 286.8 & 438.4 & $1,143.9$ & 610.7 & 596.4 & 286.6 & $3,362.7$ \\
\hline 1999 & 227.5 & 364.6 & $1,025.4$ & 629.2 & 548.0 & 287.1 & $3,081.8$ \\
\hline 2000 & 200.8 & 312.4 & 684.4 & 587.5 & 446.6 & 337.0 & $2,568.7$ \\
\hline 2001 & 287.7 & 380.7 & $1,671.3$ & 776.1 & 941.0 & 383.3 & $4,440.1$ \\
\hline 2002 & 357.5 & 571.6 & $2,249.2$ & 636.7 & $1,041.5$ & 469.2 & $5,325.7$ \\
\hline 2003 & 382.7 & 745.2 & $3,071.1$ & 775.8 & $1,267.5$ & 600.2 & $6,842.5$ \\
\hline 2004 & 359.8 & 853.3 & $1,779.0$ & 780.7 & $881.8^{(4)}$ & 869.8 & $4,642.6$ \\
\hline 2005 & 408.2 & 746.2 & $1,966.7$ & 752.8 & 669.0 & $1,172.1$ & $5,715.0$ \\
\hline 2006 & 386.5 & 788.5 & $1,987.8$ & $1,058.9$ & 747.3 & $1,253.1$ & $6,222.1$ \\
\hline 2007 & 429.3 & 752.3 & $2,050.3$ & $1,127.5$ & 941.8 & 901.7 & $6,202.9$ \\
\hline 2008 & 389.1 & $1,037.3$ & $1,344.1$ & 706.2 & $1,114.9$ & 163.1 & $4,754.7$ \\
\hline YTD '07 & 429.3 & 752.3 & $2,050.3$ & $1,127.5$ & 941.8 & 901.6 & $6,202.8$ \\
\hline YTD '08 & 389.1 & $1,037.3$ & $1,344.1$ & 706.2 & $1,114.9$ & 163.1 & $4,754.7$ \\
\hline \% Change & $-9.4 \%$ & $37.9 \%$ & $-34.4 \%$ & $-37.4 \%$ & $18.4 \%$ & $-81.9 \%$ & $-23.3 \%$ \\
\hline \multicolumn{8}{|c|}{${ }^{1}$ Interest bearing marketable coupon public debt. } \\
\hline \multicolumn{8}{|c|}{${ }^{2}$ Includes GNMA, FNMA, and FHLMC mortgage-backed securities and CMOs and private-label MBS/CMOs. } \\
\hline \multicolumn{8}{|c|}{${ }^{3}$ Includes all non-convertible debt, MTNs and Yankee bonds, but excludes CDs and federal agency debt. } \\
\hline \multicolumn{8}{|c|}{${ }^{4}$ Beginning with 2004, Sallie Mae has been excluded due to privatization. } \\
\hline Sources: & \multicolumn{7}{|c|}{ U.S. Department of Treasury, Federal Agencies, Thomson Financial, Inside MBS \& ABS, Bloomberg. } \\
\hline
\end{tabular}

In contrast, securitization does not involve any traded equity. The SPV only issues bonds rated investment-grade. As mentioned above, even studies of corporate bond returns have mainly concluded that investment-grade bonds behave like Treasury bonds while below investment-grade bonds are more sensitive to stock returns. These results were prior to credit derivatives, which now allow for speculation in corporate bonds without having to find the cash instrument.

The securitization bonds will play an important role in what follows. Securitization is, or was, quantitatively significant, as shown in the table below. The table shows issuance levels, not outstanding amounts. 


\begin{tabular}{|cccccccc|}
\hline \multicolumn{7}{|c|}{ Outstanding Amounts Various Non-Mortgage Asset-Backed Securities (\$̧bil.) } \\
\hline & Automobile & Credit Card & $\begin{array}{c}\text { Home } \\
\text { Equity }\end{array}$ & Manufactured & Student & & \\
\hline $\mathbf{1 9 9 6}$ & 71.4 & 180.7 & 51.6 & 14.6 & 10.1 & 76.0 & 404.4 \\
\hline $\mathbf{1 9 9 7}$ & 77.0 & 214.5 & 90.2 & 19.1 & 18.3 & 116.7 & 535.8 \\
\hline $\mathbf{1 9 9 8}$ & 86.9 & 236.7 & 124.2 & 25.0 & 25.0 & 233.7 & 731.5 \\
\hline $\mathbf{1 9 9 9}$ & 114.1 & 257.9 & 141.9 & 33.8 & 36.4 & 316.7 & 900.8 \\
\hline $\mathbf{2 0 0 0}$ & 133.1 & 306.3 & 151.5 & 36.9 & 41.1 & 402.9 & $1,071.8$ \\
\hline $\mathbf{2 0 0 1}$ & 187.9 & 361.9 & 185.1 & 42.7 & 60.2 & 443.4 & $1,281.2$ \\
\hline $\mathbf{2 0 0 2}$ & 221.7 & 397.9 & 286.5 & 44.5 & 74.4 & 518.2 & $1,543.2$ \\
\hline $\mathbf{2 0 0 3}$ & 234.5 & 401.9 & 346.0 & 44.3 & 99.2 & 567.8 & $1,693.7$ \\
\hline $\mathbf{2 0 0 4}$ & 232.1 & 390.7 & 454.0 & 42.2 & 115.2 & 593.6 & $1,827.8$ \\
\hline $\mathbf{2 0 0 5}$ & 219.7 & 356.7 & 551.1 & 34.5 & 153.2 & 640.0 & $1,955.2$ \\
\hline $\mathbf{2 0 0 6}$ & 202.4 & 339.9 & 581.2 & 28.8 & 183.6 & 794.5 & $2,130.4$ \\
\hline $\mathbf{2 0 0 7}$ & 198.5 & 347.8 & 585.6 & 26.9 & 243.9 & $1,069.7$ & $2,472.4$ \\
\hline $\mathbf{2 0 0 8}$ & 137.7 & 314.1 & 395.5 & 20.0 & 239.5 & 1565.0 & $2,671.8$ \\
\hline
\end{tabular}

Source: Bond Market Association, Bloomberg.

To provide a sense of the significance of these numbers, they can be compared to the amounts that remain on the banks' balance sheets, for example. The figure below shows the ratio of the securitized amounts of credit card receivables to the amount of receivables not securitized, and remaining on bank balance sheets. In 2002 and 2003, the ratio is about 1.7 in favor of off-balance sheet financing, though it has fallen to just less than one lately. A ratio of 1.7 means that for every dollar of on-balance sheet credit card receivables, there is 1.7 dollars of off-balance sheet credit card receivables. 


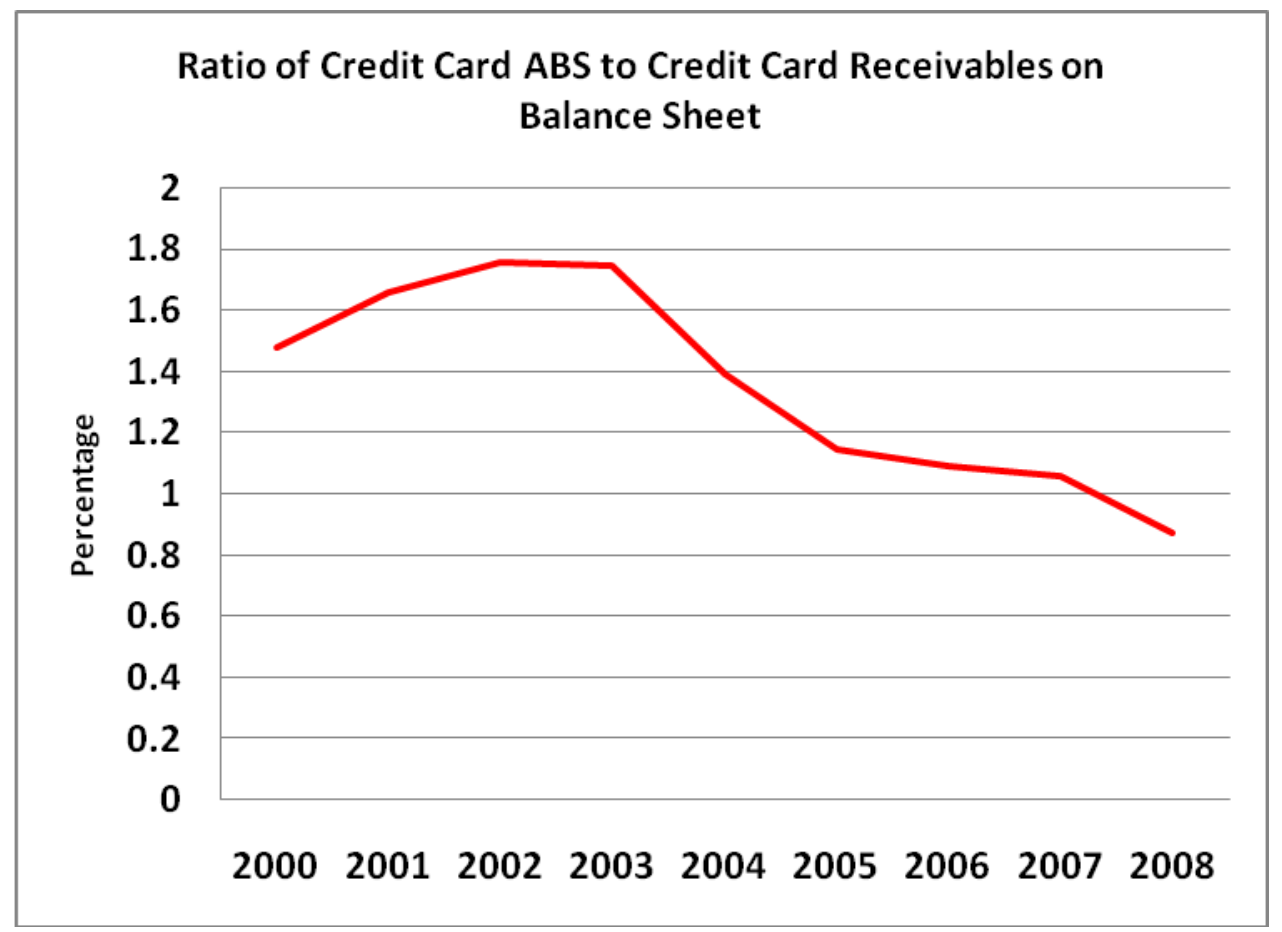

Why did securitization arise? We do not know for sure. One possibility, discussed further below, is that it was a response to bank capital requirements, which created a cost without a countervailing benefit. Banks, being private institutions, can exit the industry if it is not profitable. Another possibility is that the demand for collateral made securitization profitable, and this could not be accomplished on-balance sheet because deposit insurance was limited. That is, as discussed above, the demand for informationally-insensitive securities to use as collateral for various purposes may also have played a role. Third, bankruptcy costs are minimized with off-balance sheet financing. But, the off-balance sheet debt is not tax advantaged for the originator. See Gorton and Souleles (2006). Thus, one would expect that companies with lower credit ratings would find it optimal to securitize. Finally, the innovation in structuring the special purpose vehicle as an off-balance sheet vehicle may have been the driving forth for growth. Whatever the cause, securitization has become a very significant form of financing.

Another aspect of the development of banking off-balance sheet is loan sales, which refers to the sale of secondary participations in commercial and industrial loans to firms. This is not the way that banks operated for hundreds of years. Instead, bank loans resided on bank balance sheets until maturity. And, as mentioned above, academic theory says that only if the bank holds the loan will it have an incentive to produce information and monitor, and argument which also suggests that securitization should not occur.

The table below shows the extent of commercial and industrial loan sales. The figure below the table shows the ratio of loans sold to loans retained on-balance sheet. The ratio peaks at about one quarter in 2006. That is, for every dollar lent, one quarter is sold. In fact, loans are now rated, and trade like bonds. 


\begin{tabular}{|c|c|c|}
\hline Year & C\&I Loans (\$bil) & $\begin{array}{l}\text { Secondary Market } \\
\text { Volume (\$bil) }\end{array}$ \\
\hline 1991 & 632.8 & 8.0 \\
\hline 1992 & 607.3 & 11.1 \\
\hline 1993 & 593.9 & 15.0 \\
\hline 1994 & 619.6 & 20.8 \\
\hline 1995 & 695.2 & 33.8 \\
\hline 1996 & 750.4 & 39.5 \\
\hline 1997 & 816.3 & 60.6 \\
\hline 1998 & 896.2 & 77.6 \\
\hline 1999 & 956.3 & 79.1 \\
\hline 2000 & 1046.5 & 102.0 \\
\hline 2001 & 1062.8 & 117.5 \\
\hline 2002 & 982.5 & 112.5 \\
\hline 2003 & 917.7 & 144.6 \\
\hline 2004 & 893.8 & 155.0 \\
\hline 2005 & 900.7 & 176.3 \\
\hline 2006 & 1126.4 & 238.6 \\
\hline 2007 & 1295.3 & 342.0 \\
\hline 2008 & 1521.1 & 318.4 \\
\hline
\end{tabular}

Sources: Commercial and Industrial Loans from Federal Reserve H.8 release; loan sales from Reuters Loan Pricing Corporation.

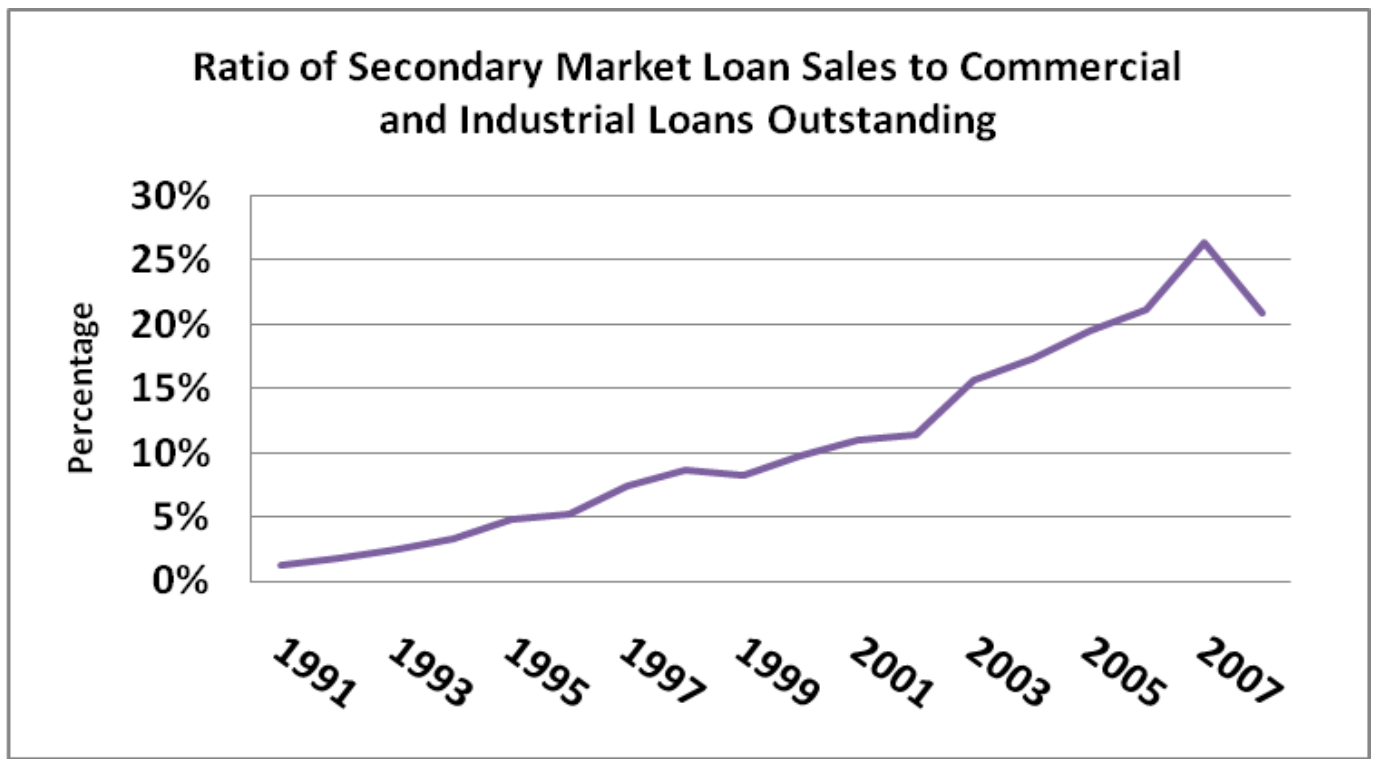


The above figure and table contradict the prevailing academic paradigm for the existence of banks, a paradigm in which banks cannot sell loans because then they have no incentive to behave, producing initial information and monitoring borrowers. There is little evidence that these incentives have broken down, or that this plays an important role in the panic. ${ }^{31}$ As Gorton and Metrick (2009) argue, nonsubprime related asset classes, like credit card securitization and loan sales, show no problems until the interbank repo market panics. We turn to repo next.

\section{B. The Rise of Repo}

The rise of securitization coincided with the increased demands for collateral, discussed above. Further, securitization required changes in the financial infrastructure. Investment and commercial banks that sponsored securitizations often buy loan portfolios to sell to SPVs and then hold the SPV-issued bonds until they can be sold. This meant that the balance sheets of dealer banks, in particular, had to increase in size and this had to be financed somehow. Gorton and Metrick (2009) show this to be the case. Firms also, apparently, had a need for a place to deposit short term cash. These factors led to an enormous growth in the sale and repurchase ("repo") market, a short-term collateralized lending market. The repo market traditionally was confined to U.S. Treasury securities, but in the last 25 years it has grown to accept a broad range of securitized bonds as collateral. Asset classes that came to be eligible for repo included all manner of securitized products, as well as tranches of structured products like collateral debt obligations.

The importance of the repo market is suggested by its immense size: primary dealers reported financing \$4.5 trillion in fixed income securities with repos as of March 4, 2008.

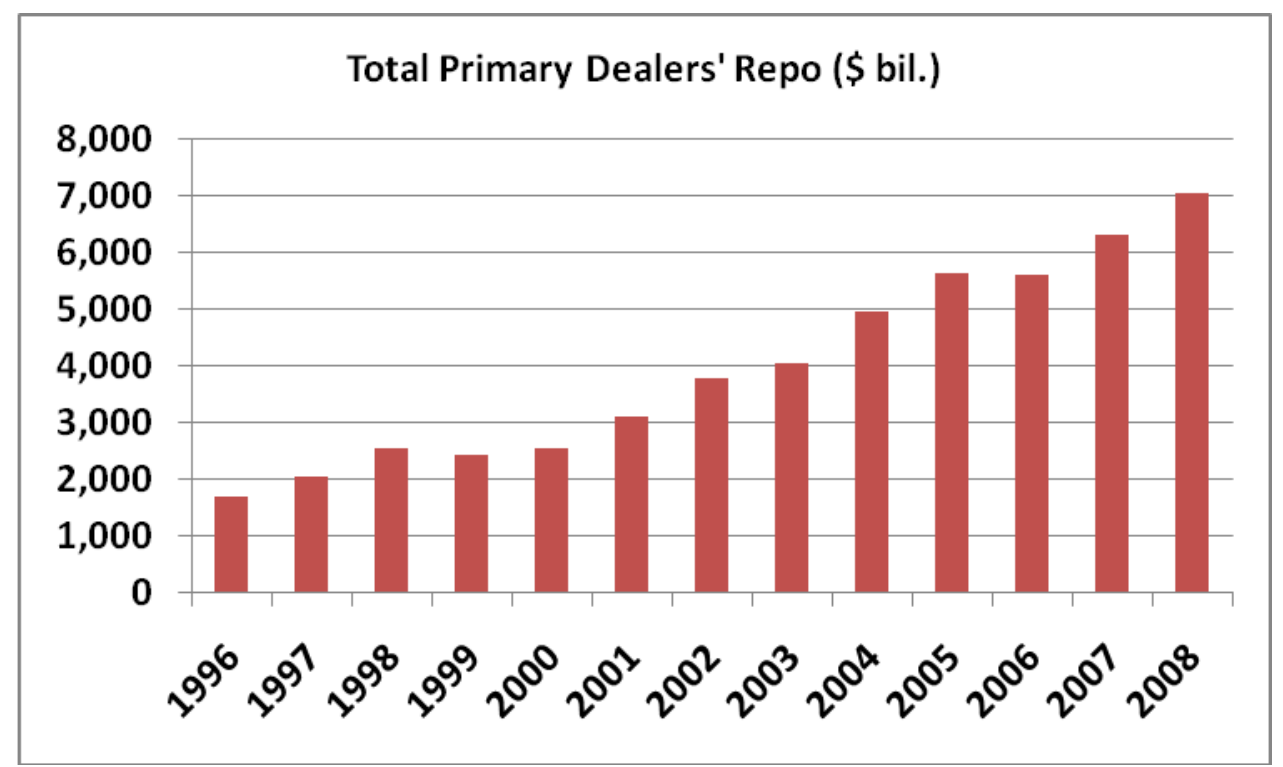

Source: Federal Reserve.

\footnotetext{
${ }^{31}$ The assertion that there is a break-down of incentives - the "originate-to-distribute" view - is discussed in Gorton (2008).
} 
These numbers, while large, do not include all the repo that non-primary dealers undertake. There are no official statistics about the size of the overall repo market, but unofficial guesses put the market at somewhere around $\$ 10$ trillion dollars, though that may include double counting of repo and reverse repo (i.e., both sides of the transaction). For comparison, the total assets of the regulated U.S. banking sector are also about $\$ 10$ trillion.

Repo is essentially depository banking, built around informationally-insensitive debt. In a repo transaction, one side of the transaction wants to borrow money and the other side wants to save money by "depositing" it somewhere safe. Think of the borrowers as a "bank" and the lender as a "depositor," although the lender is another firm, such as a bank, insurance company, pension fund, institutional investor, or hedge fund. The depositor receives a bond as collateral for his deposit.

When the depositor deposits money, the collateral may involve a "haircut" or margin. The haircut is the percentage difference between the market value of the pledged collateral and the amount of funds lent. For example, a haircut of 5\% means that a "bank" can borrow \$95 for each \$100 in pledged collateral. A haircut further protects the depositor against the risk of borrower default by the "bank." The size of the haircut reflects the credit risk of the borrower and the riskiness of the pledged collateral.

Another important feature of repo is that the collateral can be rehypothecated. In other words, the collateral received by the depositor can be used - "spent" - in another transaction, i.e., it can be used to collateralize a transaction with another party. Intuitively, rehypothecation is tantamount to conducting transactions with the collateral received against the deposit. There is no data on the extent of rehypothecation.

\section{Summary}

The shadow banking system is, in fact, a banking system. The "depositors" are firms seeking a place to save cash in the short-term, often money market funds and corporations. The "lenders" are financial firms seeking cash to finance themselves. The deposits are designed to be informationally-insensitive by backing them with informationally-insensitive collateral. Often that collateral is securitization bond. The collateral can be "spent," i.e., rehypothecated. Depositors can "withdraw" their funds by not rolling over their repo agreements, and returning the bond, or they can withdraw by increasing the haircut on the collateral. ${ }^{32}$ This is depository banking in a different form, but banking nevertheless. Like demand deposits at regulated commercial banks, this system is vulnerable to panic.

It is easy to summon up the old adage that one should not borrow short to finance long assets, but the reality is that banking inevitably involves that because part of making the "deposit" near riskless is for it to be short maturity. Note that with insured deposits, the debt is effectively long maturity because

32 Of course, the issue of whether the "bank" is solvent will arise. Repo is an exception to the U.S. Bankruptcy Code. If the lender fails, the non-defaulting party - the depositor in this case-has the option to unilaterally terminate the repo agreement and keep the bond (or go into Chapter 11). The issue that arises in the next section concerns whether the bond is liquid. 
depositors have no need to run their banks to try to withdraw cash. The shadow banking system resembles the pre-FDIC U.S. banking system in some ways.

\section{The Panic}

That astonishing disturbance and collapse of credit [during the Panic of 1907] was one of the most unbecoming, if not disgraceful, episodes in our financial history. Popular clamor followed. When the air had cleared it was seen that the trouble was due to the banking system, which, ill-adapted to supply the needs of a progressive industrial nation under normal conditions, was utterly inadequate for the preservation of business equilibrium and the allaying of distrust in times of business accident and unexpected strain. Weston (1922, p. 17)

What caused the panic? The short answer is that there was a shock and, like panics in the National Banking Era, there was asymmetric information about where the exposures to this shock were located. The Panic of 2007 chronology has been outlined by Gorton (2008), and the details will not be repeated here. The key question to be addressed to understand the panic is why asset classes completely unrelated to subprime asset classes saw their spreads rise to distress levels. The fundamentals of subprime deteriorated, so asset classes linked to subprime should have declined in value. But, that is not a systemic event. The systemic event concerns the collapse of the prices of other asset classes. Gorton and Metrick (2009) and Gorton (2009) address the question of why asset classes other than those related to subprime suffered declines in value. This section draws on those studies.

As explained in Gorton (2008), the particular design of subprime mortgages made them especially sensitive to house prices. The shock to fundamentals was the failure of home prices to rise. Indeed, they later fall. This shock was revealed in the only market that was widely observable within the nexus of derivatives and structured products involved in the panic. Dealer banks launched the ABX.HE (ABX) index in January 2006. The $A B X$ Index is a credit derivative that references 20 equally-weighted subprime RMBS tranches. There are also sub-indices linked to a basket of subprime bonds with specific ratings: $A A A, A A, A B B B$ and $B B B-$. Each sub-index references the 20 subprime RMBS bonds with the rating level of the subindex. ${ }^{33}$

The introduction of the $A B X$ indices opened a (relatively) liquid, publicly observable market, which priced subprime risk. See Gorton (2009). The other subprime-related instruments, RMBS and CDOs, did not trade in publicly observable markets. In fact, securitized products generally have no secondary

\footnotetext{
${ }^{33}$ Every six months the indices are reconstituted based on a pre-identified set of rules, and a new vintage of the index and sub-indices are issued. Only four vintages were issued, two in 2006 and two in 2007. The index is overseen by Markit Partners. The dealers provide Markit Partners with daily and monthly marks. See http://www.markit.com/information/products/abx.html.
} 
trading that is publicly visible. Thus, for our purposes the $A B X$ indices are important because of the information revelation about the value of subprime mortgages, which in turn depends on house prices. ${ }^{34}$ Gorton and Metrick (2009) track the timing of movements in the ABX. The ABX.HE Indices showed a steady deterioration of subprime fundamentals, starting in early 2007. Gorton and Metrick also show that subprime related asset classes and firms also deteriorate along with the ABX. Examples of these deteriorating asset classes include tranches of collateralized debt obligations, BBB subprime tranches, BBB commercial mortgage-backed securities. Countrywide and Washington Mutual, and the monoline insurance companies, are example of firms whose fates moved with the ABX.

However, significantly, other asset classes do not show deterioration (spreads rising) with deterioration in the ABX. That is, the shock to subprime per se was not the cause of the panic. Other asset classes only experience difficulties when there are problems in the interbank market, starting in August 2007. Gorton and Metrick (2009) study the spread between three-month LIBOR and the three-month overnight index swap (OIS). As they explain, this spread should be zero by no-arbitrage, except for transactions costs. Indeed, this spread historically has been about eight basis points.

The Libor-OIS spread jumps in August 2007, and again when Lehman fails. Other securitized asset classes, with nothing to do with subprime, like credit card receivables, auto loans, and student loans, all move with the proxy for the state of the inter-bank market, not with the ABX. See Gorton and Metrick (2009). The key question for understanding the panic is: Why were non-subprime-related asset classes affected? Subprime mortgage originations in 2005 and 2006 totaled about \$1.2 trillion (see Gorton (2008)), a large number to be sure, but not large enough to cause a systemic crisis. How was the shock turned into a panic?

The shock was combined with asymmetric information about the locations and sizes of exposures to subprime. Like the panics during the National Banking Era, it was not clear which firms had the largest exposures. During the National Banking Era, depositors did not know which banks were more likely to fail during the recession. They just knew that they were exposed to the risk that their bank would be insolvent during the recession, just when they might be unemployed. So, they "ran" to their bank to withdraw cash. The banks' equity cushion and their assets-the collateral-were not to be trusted.

The same mechanism operated this time. The "depositors" are firms that have deposited money in the form of (reverse) repo, and received a bond as collateral. Prior to the panic, repo haircuts were zero. The run occurs in the repo market.

\footnotetext{
${ }^{34}$ Keep in mind that house price indices, like the S\&P Case-Shiller Indices, are calculated with a two month lag. Furthermore, house price indices are not directly relevant because of the complicated structure of subprime securitizations (see Gorton (2008)).
} 


\section{A. The Run on Repo}

Uncertain about the solvency of counterparties, repo depositors became concerned that the collateral bonds might not be liquid; if all firms wanted to hold cash - a flight to quality-then collateral would have to decline in price to find buyers. This is the crucial link between the subprime shock and other asset categories. Gorton and Metrick show that the other asset classes start to deteriorate in August 2007, when the LIBOR-OIS spread jumps, even though the subprime fundamentals, as measured by the $A B X$, had been deteriorating for months prior to that.

The run on repo is, again, akin to previous panics. "Withdrawal" corresponds to an increase in haircuts. So, previously when $\$ 100$ was "deposited," collateral in the form of a bond worth $\$ 100$ in the market was acceptable. In August 2007, the haircuts went up in some important asset classes. Say, the haircut increases to five percent. Then the depositor deposits only $\$ 95$ in exchange for collateral worth $\$ 100$.

The figure below shows the average repo haircut on seven categories of structured debt. The figure is based on data from Gorton and Metrick (2009), which also has the details underlying this figure. Also see Gorton (2009). The figure is a picture of the panic. Haircuts were zero until August 2007. After that, haircuts rise and continue to rise.

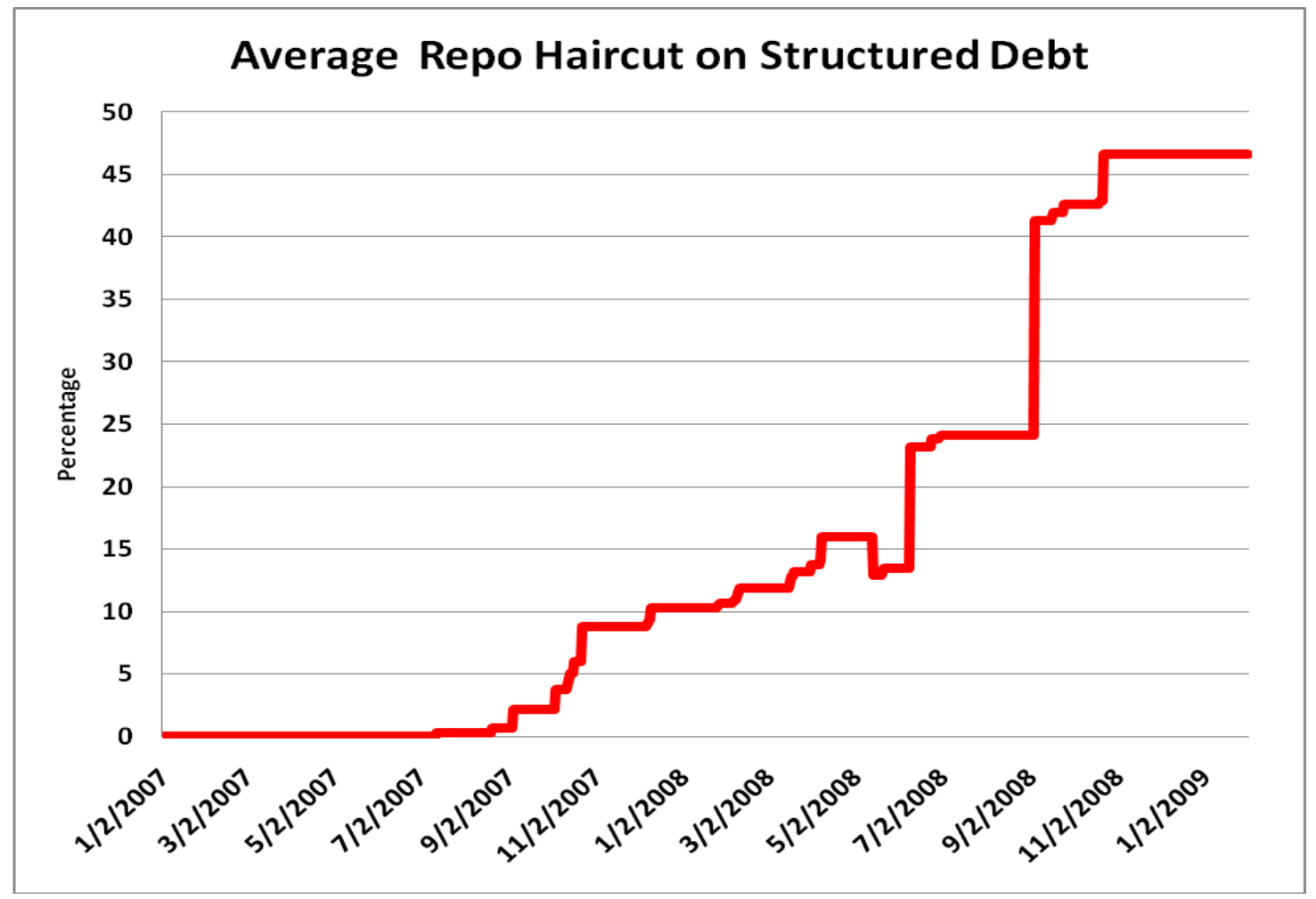

Source: See Gorton and Metrick (2009).

The increasing haircuts are tantamount to withdrawals from the "bank." What does this mean? The figure on the next page provides a stylized balance sheet for the "banking" system. Inititally, the banking system has assets of $\$ 100$ financed by equity capital of $\$ 10$, long-term debtof $\$ 40$, and short 
term financing in the form of repo of $\$ 50 .{ }^{35}$ In the panic, repo haircuts rise to 20 percent, amounting to a withdrawl of $\$ 10$, so the system has to either shrink, borrow, or get an equity injection to make up for this. As we saw, after some early equity injections during the fall of 2007 , this source dried up, as did the possibility of borrowing. That leaves asset sales. So the system as a whole needs to sell $\$ 10$ of assets. But this causes prices to go down (and collateral values to fall). In panel $\mathrm{C}$ of the figure some assets were sold, and the prices fell on others. Assets are now worth $\$ 80$; equity is wiped out. The system is insolvent.

The reality is that there is no private agent large enough to buy enough of the assets of the system to solve the problem. Left with the only alternative, namely, selling assets, the outcome is simply that prices fall.

There are no official figures for the size of the repo market, beyond primary dealers. Also, there are no official data on repo haircuts. Consequently, it is hard to put hard numbers on the above stylized example. Estimates of the size of the repo market are that it is roughly $\$ 8$ trillion to $\$ 10$ trillion. If repo haircuts increase to an average 20 percent (a guess), then between $\$ 1.6$ - $\$ 2$ trillion must be raised by the banking system. Without investors willing to finance this by investing in these firms, the only alternative is to sell assets. Like panics during the National Banking System, the system is insolvent. It is worth recalling the clearinghouse loan certificate process. The New York Times (November 17, 1890, p. 4), explained as follows:

[Clearinghouse loan certificates] use may be compactly defined as the protection of values against panic. They accomplish that by enabling the several banks to obtain and give credit to real value of securities, instead of being forced to throw those securities upon a panic-stricken market, which would be certain slaughter and inevitable ruin for creditors and debtors alike. In other words, the banks as a body, the "Associated Banks," the "Clearing House," offer their joint guarantee of the real value of property and they can judge of soundly and wisely and enable that property to be used at its real value when no individual could know its worth, or could act on if he thought he knew it. The simplicity of the process...conceals its immense importance. But, it is, in reality, one of the most marvelous developments of modern commercial life.

\footnotetext{
${ }^{35}$ Hördahl and King (2008), "the (former) top US investment banks funded roughly half of their assets using repo markets, with additional exposure due to off-balance sheet financing of their customers" (p. 39).
} 
Figure: The Systemic Affects of the Repo Market Panic

A. The initial state of the "banking" system, with 10 percent equity.

\begin{tabular}{l|l}
\multicolumn{1}{c}{ Assets } & Liabilities \\
\hline 100 & 10 Equity Capital \\
& 40 Long-Term Debt \\
& 50 Repo \\
\hline 100 & 100
\end{tabular}

B. Repo haircuts increase from zero to 20 percent - not an equilibrium.

\begin{tabular}{l|l}
\multicolumn{1}{c}{ Assets } & Liabilities \\
\hline 100 & 10 Equity Capital \\
& 40 Long-Term Debt \\
& 40 Repo \\
\hline 100 & 90
\end{tabular}

C. The System sells assets, causing asset prices to fall.

\begin{tabular}{l|l}
\multicolumn{1}{c}{ Assets } & \multicolumn{1}{l}{ Liabilities } \\
\hline 80 & 0 Equity Capital \\
& 40 Long-Term Debt \\
& 40 Repo \\
\hline 80 & 80
\end{tabular}




\section{B. The Shortage of Collateral - the "Currency Famine"}

"Quite understandably, [central bank counterparties] have economized on the use of central government bonds which has been often almost the only collateral counterparties could still use in interbank repo markets. Instead they have brought forward less liquid collateral...including ABSs, for which primary and secondary markets have basically dried up." José Manuel González-Páramo, ECB Executive Board Member, June, 2008. (Quoted by Chailloux, Gray, and McCaughrin (2008).)

The increase in haircuts means that there is a shortage of collateral. There is an excess demand for U.S. Treasuries because of the flight to quality generally. The evidence of this is provided by Gorton (2009) and Gorton and Metrick (2009) who point to the very large increase in Treasury repo fails. A repo "fail" occurs when the party with the bond has rehypothecated the bond and then cannot find an acceptable bond to return when the repo matures. A repo fail is not an event of default. See Fleming and Garbade (2005). Total fails in Treasury repos reached a record $\$ 5.1$ trillion in October 2008. For comparison, total fails averaged \$165 billion per week between 1990 (when the Fed started collecting data) to July 2007.

Gorton and Metrick (2009) document that at even larger spike upwards in the LIBOR-OIS spread occurs just after Lehman fails. As shown in the figure on repo haircuts, haircuts continue to increase, with some asset classes becoming simply unacceptable in repo. The aftermath of Lehman wreaked further havoc in the interbank market. One effect was that the extent of rehypothecation significantly declined; see Singh and Aitken (2009). Singh and Aitken examine 100 filings of major firms and find "that since end-2007 the decline in rehypothecation (i.e., total collateral received that can be pledged) by the largest four broker-dealers was $\$ 1.774$ trillion" (p. 5).

The other effect of the Lehman failure was the fear about daylight risk exposure. This is a kind of settlement risk, which occurs when a party faces possible loss between the time a settlement payment is made and a corresponding payment is received (usually in another currency) on the same business day. In over-the-counter markets settlement sometimes takes between a day to three days but after Lehman, firms hoarded cash, only trading on a delivery-versus-payment basis, i.e., no delay between exchange of cash and the security. It is difficult to document this, but the BIS (2008b, p. 26) reported a contraction of $\$ 423$ billion in the U.S. dollar interbank borrowing market. Gorton and Metrick (2009) analyze the spike in the LIBOR - overnight index swap spread upon the collapse of Lehman, consistent with idea that "global interbank markets seized up, curbing banks' access to short-term funding" BIS (2008, p. 9).

\section{Complexity Revealed When Debt Becomes Informationally-Sensitive}

A panic is an event where informationally-insensitive debt becomes informationally-sensitive. It is a switch because it becomes profitable to produce private information about the debt. That is, some agents are willing to spend resources to learn private information to speculate on the value of these 
securities. This was not profitable before the panic. This leads to a "lemons market" in which everyone needs to suddenly produce information to trade. ${ }^{36}$

This is a devastating regime switch because market participants are not prepared to cope with the sudden information requirements for understanding, valuing, and trading securities that are suddenly informationally-sensitive. Part of the crisis is the aftermath in which securities that previously were informationally-insensitive become informationally-sensitive. This makes them illiquid. Not only does information now have to be produced, but the expertise is lacking. In the current environment, given the panic, the complexity of the underlying structure, which Gorton (2008) described as a chain of structures, matters a great deal. Gorton (2008) discusses this complexity in detail.

\section{Summary}

Perhaps a useful way to summarize the Panic of 2007 is to contrast it with the panics of the National Banking Era.

- Like the banking panics during the National Banking Era, the Panic of 2007 was caused by a shock, to housing prices. The panic started in August 2007. The National Bureau of Economic Research dates the peak of the business cycle at December 2007.

- "Depositors" were firms that lent money in the repo market (engaged in reverse repos). The location of subprime risks among their counterparties was not known. Depositors were confused about which counterparties were really at risk and consequently ran all banks. In other words, repo haircuts increased, tantamount to withdrawal. How do we know depositors were confused about which banks were at risk? The evidence is that non-subprime related asset classes saw their spreads rise significantly only when the interbank market started to breakdown.

- A banking panic is a systemic event because the banking system as a whole is insolvent. How do we know that the banking system was insolvent? There is no direct evidence, although bank-of the envelope calculations suggest that the banking system needed to replace about $\$ 2$ trillion of financing when the repo market haircuts rose.

- Did asset prices fall during the Panic of 2007 panics? Asset prices did fall. To the extent that they can be measured, the prices of non-subprime related assets fell significantly. See Gorton and Metrick (2009). Financial firms could only delever in response to the increase in haircuts by selling assets. There was no suspension of convertibility (or of "mark-to-market" accounting). Consequently, financial firms had to try sell loans and mortgages.

\footnotetext{
${ }^{36}$ The "lemons market" refers to a market in which one side of a transaction has information about the true value of something, but the other side does not. As a result, parties can try to sell overvalued cars or securities, or whatever. But, then the parties with undervalued things to sell leave the market. See Akerlof (1970).
} 
- In a panic cash is hoarded and there is a shortage of transactions mediums. In the Panic of 2007, U.S. Treasuries were hoarded. We know this from repo fails. And there was a shortage of collateral.

The similarities and differences between the National Banking Era panics and the Panic of 2007 are revealing. On the one hand, the similarities strongly suggest that the interpretation of repo as banking is correct. On the other hand, the main difference was that there was no clearinghouse response, no suspension of convertibility. And, obviously there was no "deposit" insurance in either case.

\section{The Future Financial Landscape}

A study of the crises of 1873,1893 and 1907 , and of the numerous minor critical periods in the financial history of the last generation is not calculated to impress one with the smooth working of our banking machinery. No other advanced country in the civilized world has experienced such a disastrous series of financial collapses, suspensions, disrupted exchanges, and currency makeshifts during the past forty years, as the United States. ... I am not one of those who have a panacea for currency and banking ills, and the few rather commonplace suggestions I have to make at this time are tentative, and, like railroad time tables, "subject to change without notice." Kemmerer (1911)

It is very difficult to see what the financial landscape will look like in five or ten years. Surely that will depend, in large part, on new regulations. What should be the new regulations? The answer to that question depends on what the problem is that resulted in a panic. In this section, two, related, issues are very briefly addressed. First, answers to these questions are discussed: what explains the Quiet Period in U.S. banking that was experienced from 1934-2007, why did it end, and can it be reproduced ? $^{37}$ And, second, what should be done about the shadow banking system?

\section{A. Explaining the Rise and Fall of the Quiet Period in U.S. Banking}

Following the introduction of deposit insurance in 1934, the long period of quiescence in U.S. banking started, broken by the savings and loan ( $\&$ L) crisis and bank failures during the business cycle starting in July 1990. But, there was no systemic event in banking until 2007. Some explanation for how society achieved the long period of quiet in banking may provide some clues to how to once again obtain that goal. Since financial innovation is inevitable, whether such a period can be made permanent or not is hard to determine.

The Quiet Period in U.S. banking was a period in which demand deposits were insured and entry into banking was limited. ${ }^{38}$ Firms called "banks" were well-defined; they took in deposits and made loans. To

\footnotetext{
${ }^{37}$ The Quiet Period also corresponds to a less skill intensive, lower paid, financial sector. See Philippon and Reshef (2008).

38 Insuring demand deposits, something we take for granted, was controversial at the time of adoption: "many bankers and economists protested" Taggart and Jennings (1934, p. 508).
} 
do this, banks had to obtain a charter from either the federal or state government, and this was very restrictive (see Peltzman (1965)). Until the Monetary Control Act of 1980 there were interest rate ceilings of deposits (Regulation Q). Due to limited entry, banks had local monopolies on deposits, e.g., see Neumark and Sharpe (1992), who show that "banks in concentrated markets are slower to raise interest rates on deposits in response to rising market interest rates, bur are faster to reduce them in response to declining market interest rates" (p. 657). Also, see Hannan and Berger (1991). Bank charters were valuable, providing an incentive for banks to self-regulate. This explains why banks do not appear to have engaged in the moral hazards that are alleged to follow from government deposit insurance. See Keeley (1990) and Marcus (1984). The Quiet Period followed from a combination of "sticks" and "carrots." Banks faced the "stick" of bank regulations and examinations, but also had the "carrot," in the form of monopoly rents that made the charter valuable.

In the early 1990s competition from non-banks (e.g., money market mutual funds, junk bonds), and deregulation (e.g., of interest rate ceilings) caused bank charter values to decline, which in turn caused banks to increase risk and reduce capital. This has been documented by Keeley (1990). Also, see Berger, Kashyap, and Scalise (1995). Keeley noted an increase in risk-taking and a decline in capital levels. The carrot essentially disappeared and regulators increasingly relied on the stick, and that was increasingly capital requirements. Whether this caused "banking" to move out of banks or not is less clear. Gorton and Winton (2000) argue that if regulators impose capital requirements that are binding, when there is no carrot in the form of a valuable charter, then bank capital will exit the (chartered bank) industry. Again, we do not know for certain if that was, in fact, the cause of capital to exit regulated banking to the shadow banking system. But, in any case, the shadow banking system developed coincidentally with the disappearance of charter value. This development was fairly long in the making, but was not hidden. It was there for all to see. ${ }^{39}$ Gorton (1994), in a paper entitled "Bank Regulation When 'Banks' and 'Banking' Are Not the Same," noted that banking had significantly metamorphosed into something different.

Without the carrot of a valuable charter, providing an incentive to self-regulate and monitor risk, it seems unlikely that the stick alone can create a new period of quiet.

\section{B. What should be done about the Shadow Banking System?}

What should be done about bank regulation? A good starting point is the recognition that (1) there is a demand for collateral by firms for many purposes and, (2), there is the need for a safe way for firms to save cash in the short-term. The shadow banking system arose to meet these demands. Securitization created collateral and the repo market provides a banking mechanism for firms and institutional investors. Collateral means informationally-insensitive debt. Firms could be provided a safe savings location with large size insured accounts at banks. But, forcing everything back on-balance sheet does not solve the collateral problem. Collateral is needed for derivatives and settlement, as well as for

\footnotetext{
${ }^{39}$ For example, Pozdena (1986) discusses "the causes of rapid growth in securitization" almost 25 years ago. He writes: "Securitization is . . one manifestation of how financial innovation - driven by technological and other changes - is moving some parts of financing activity away from financial intermediaries."
} 
savings in the form of repo. Forcing everything back on balance sheet seems like an attempt to return to the Eden of the Quiet Period without recognizing that the world has changed.

Further, as discussed above, a key part of the Quiet Period was a valuable bank charter, which provided an incentive to self-regulate. If the shadow banking system is recognized as a genuine banking system, then perhaps the Quiet Period for this banking system can be achieved by creating charter value and informationally-insensitive debt. Very broadly this would mean three things:

1. Senior tranches of securitizations of approved asset classes should be insured by the government.

2. The government must supervise and examine "banks," i.e., securitizations, rather than rely on ratings agencies. That is, the choices of asset class, portfolio, and tranching must be overseen be examiners.

3. Entry into securitization should be limited, and any firm that enters is deemed a "bank" and subject to supervision.

Informationally-insensitive debt is created by points 1 and 2, which then provides a way for repo to serve as a short-term savings mechanism for firms. Point 3 creates charter value for firms that engage in the production of the new informationally-insensitive debt. Being able to securitize is valuable.

These three points simply highlight the kind of thinking needed if it is agreed that shadow banking is real banking, which needs to be protected. The alternative viewpoint seems somewhat problematical because the rise of securitization and repo as very significant parts of the capital markets cannot be explained as a bubble, or as the product of greed, and so on. The "originate-to-distribute" viewpoint, discussed by Gorton (2008), is the view that appears to securitization per se is the problem, again an attempt to rationalize going back to the view of pushing everything back on balance sheet.

The demands for more informationally-insensitive debt to serve as collateral have been hard to satisfy and the economy needs more of it. That is the modern equivalent of saying that consumers need insurance for their demand deposits. Imagine that we had had the broad system outlined above. Under point 2, would the government have rejected subprime securitization as eligible for insured collateral? Probably not. The government probably cannot do better than private entities. But, the effects of the mistake would have been different. The government would have borne the losses on the AAA and AA rated tranches (assuming those were insured) and a systemic event would have been avoided.

It is important to emphasize the implications of "informationally-insensitive" debt. Whenever debt is created, a residual security is also created by definition. So, to the extent that there is a demand for informationally-insensitive debt, there must also be a residing place for the very informationallysensitive residuals (equity) that are a by-product of this debt creation. Creation of a valuable charter is intended to address that risk. As Keeley (1990) highlights, the usual "moral hazard" argument about banks and deposit insurance did not have any force during the Quiet Period, because of the valuable charter. 


\section{The History of Bank Regulatory Policy}

If there is anything to be learned from U.S. history, it is that the Quiet Period was rare and that it is hard to create. Every time a major banking reform was enacted, it was hailed and then failed. When the National Banking Act replaced the Free Banking Era (see Gorton (1996, 1999)), it was hailed. For example, the New York Times wrote:

It is now more than twelve years since the national banking system went into operation in this country.... It requires but a moderate knowledge of the banking system now in force to see that, whatever may be its defects, and whatever the errors of the managers doing business under it, it can never inflict the same kind of loss on the country as that which came from the old system. New York Times (January 16, 1877, p. 4)

What followed were the periodic panics of the National Banking Era.

Banking history is replete with many such examples. But, in each case there were problems, perhaps inevitably so. When the Federal Reserve System came into being in 1914, the clearinghouse mechanisms for dealing with panics were eliminated, and the money issuance features under the Aldrich-Vreeland Act were also eliminated. ${ }^{40}$ When the Great Depression occurred, none of the previous methods were available to deal with the panic. Clearinghouse loan certificates were not issued and, as Silber (2007a, footnote 4 on page 288) points out, the discount window was not the same as credit creation under the Aldrich Vreeland Act. These were mistakes that could have been avoided. Gorton (1988) looks at the counterfactual experiment of what would have happened during the Great Depression had the clearinghouse mechanisms been in place. The conclusion is that "if there had been a panic in December 1929, [bank] failure and loss percentages would have been an order of magnitude lower" (p. 247). Policy errors can be devastating. It was not until 1934 that the controversial idea of deposit insurance was enacted.

Of course, it is easy to observe things ex post. But, surely the lessons of history have something to offer. That history is the long search for institutions that can ensure a "sound currency," and that is still the search. Now, it requires the recognition that shadow banking is, in fact, banking, creating a "currency" for firms. The sketch of banking reform outlined above, while no more than a sketch, suggests that policy should be firmly based on an understanding of the problem, not just a reaction to the crisis.

\footnotetext{
${ }^{40}$ On the Aldrich-Vreeland Act see Silber $(2007 a, b)$.
} 


\section{Conclusion}

Each panic teaches us something new and this accumulating experience should in time enable us to prolong the interval of recurrence if not eventually to prevent the recurrence entirely, just as epidemics of disease, formerly thought inevitable, are now prevented. Marburg (1908, p. 55)

Concisely stated, the problem before us at the present time is to develop a sound banking system in the United States . . . why has the United States not found a satisfactory solution to its banking problems during the long period of agitation and reform that stretches back to 1836? Perhaps the chief reason is our habit of application - of being content with immediate remedies for pressing problems . . . To find a permanent solution we must first analyze the fundamental bases of the problem - not merely its superficial inconveniences. James $(1934$, p. 1)

Periodic banking panics have been the norm in U.S. history. But the panics appeared to end in the U.S. when deposit insurance was legislated in 1934. Combined with valuable bank charters and oversight by bank examiners, the Quiet Period was created. What changed? Bank charter values eroded under competition. Securitization is a more efficient way to finance loans. The growth of derivative securities caused an enormous demand for collateral. Over twenty-five years the shadow banking system evolved to meet the needs of this modern economy. Unfortunately, the vulnerability to panic was also produced.

The shadow banking system is, in fact, banking. Banking is about the creation of informationallyinsensitive debt. Securitized products serve the function of collateral for many purposes, but importantly in the repo market. Although the shadow banking system has been present for roughly 25 years, it was never understood to be "banking" because that was associated with chartered depository institutions. So, while the development of this system was noted, the vulnerability to panic was not noted. Keep in mind that there are no official measures of the size of the repo market, or repo haircuts or rates. There are no data on the identity of repo market participants like bank Call Reports which banks are required to file. There are no official measures of collateral usage in derivatives or settlement. There are no official measures of securitization. The shadow banking system was, as they say, "off the radar screen." But, its presence has been obvious in a general sense. No matter what new regulatory policy is proposed, discussed, debated, contemplated, or considered, surely we would be better off with information, to make an informed decision.

A banking panic is a systemic event because the banking system cannot honor commitments and is insolvent. The current panic appears to have this feature, although the panic happened in the shadow banking system, not the regulated system. Subprime related products were shocked by the decline in housing prices, but the location of these risks was not known. This shock is reminiscent of the $19^{\text {th }}$ century shocks and had the same outcome. Worried that their banks were not solvent, and concerned about the liquidity of their collateral, repo depositors increased repo haircuts, essentially demanding more equity financing of the collateral. Banks could not get enough new investment though the sale of equity or new debt, and decided to sell assets, since they could not suspend convertibility. But, the 
fundamental fact is that the private sector is too small to buy that amount of assets. Asset prices plummeted. The banking system became insolvent.

Understanding the role of the shadow banking system and the banking panic is fundamental to thinking about future regulation. Re-creation of a Quiet Period in banking depends on the existence of debt that is informationally-insensitive for banking purposes. The economy has evolved to the point where more of this type of debt is needed, by firms rather than consumers. The "banking" in question is that provided by the shadow banking system, via securitization and repo. This is banking. Policies need to be adopted to create a sufficient amount of the needed debt so that companies can engage in banking safely. The response of our predecessors to banking panics was not to outlaw demand deposits; rather it was to take the proactive step of facilitating the creation of riskless debt through insured demand deposits, combined with valuable charters and oversight.

Paradoxically perhaps, this is somewhat contrary to modern finance theory, which focuses on equity markets and extols the virtues of "market efficiency," that is the idea that equity prices contain lots of information. That may be fine for equity markets, but for much of the debt market, there should be no reason for prices to reflect a lot of information. In fact, the needs of the economy are for precisely the opposite. Demand deposits prices do not reflect the risk of the bank failing, nor do insured certificates of deposit. $^{41}$

Reforms to the current system must address the reality of shadow banking system as a banking system. It is important to get this right. We have been through this before --

There are two conceivable methods by which banking reform in the United States may be achieved. The first might be defined as the cataclysmic of panic method, being the possibility of securing legislation in the frightened desperation of an industrial panic or in the period of dull prostration which succeeds. As a mode of procedure, it is open to all of the indirection and waste of Elia's method of preparing roast pig - and to something of its uncertainty. On more than one occasion experience has shown that panic leads to the swift adoption of a remedial device, but unfortunately of a wrong one. The other method is the slower, more prosaic one of popular education and effective propaganda. Hollander (1913).

\footnotetext{
${ }^{41}$ Demand deposits could reflect the risk of the bank failing if the face value was discounted when consumers wrote checks to buy things. This was, in fact, the case for the private bank money issued during the Free Banking Era in pre-Civil War America. This market was "efficient," but was being superseded by demand deposits. See Gorton $(1996,1999)$.
} 


\section{References}

Adrian, Tobias and Hyun Song Shin (2009a), "Liquidity and Leverage," Journal of Financial Intermediation, forthcoming, (see Federal Reserve Bank of New York Staff Report, No. 328, May 2008).

Adrian, Tobias and Hyun Song Shin (2009b), "Money, Liquidity and Monetary Policy," American Economic Review Papers and Proceedings, forthcoming, (see see Federal Reserve Bank of New York Staff Report, No. 360, January 2009).

Akerlof, George (1970), “The Market for 'Lemons': Quality Uncertainty and Market Mechanism,” Quarterly Journal of Economics, Vol. 84, No. 3, 488-500.

Andrew, A. Piatt (1908a), "Hoarding in the Panic of 1907," Quarterly Journal of Economics, Vol. 22, No. 4, p. 497-516.

Andrew, A. Piatt (1908b), "Substitutes for Cash in the Panic of 1907," Quarterly Journal of Economics, Vol. 22, No. 2, p. 290-299.

Angelini, Paolo (1998), "An Analysis of Competitive Externalities in Gross Settlement Systems," Journal of Banking and Finance, Vol. 22, 1-18.

Bank for International Settlements (BIS) (2009), Committee on Payment and Settlement Systems of the Group of Ten Countries, "Statistics on Payment and Settlement in Selected Countries," (March).

Bank for International Settlements (BIS) (2008a), "Semiannual OTC Derivatives Statistics at end-June 2008."

Bank for International Settlements (BIS) (2008b), "International Banking and Financial Market Developments," BIS Quarterly Review (December).

Bank for International Settlements, Committee on Payment and Settlement Systems (2005a), "New Developments in Large-Value Payment Systems."

Bank for International Settlements, Committee on Payment and Settlement Systems (2005b), "New Developments in Large-Value Payment Systems."

Bank for International Settlements, Committee on the Global Financial System (2001), "Collateral in Wholesale Financial Markets: Recent Trends, Risk Management and Market Dynamics."

Benveniste, Lawrence, Manoj Singh, and William Wilhelm (1993), "The Failure of Drexel Burnham Lambert: Evidence on the Implications for Commercial Banks," Journal of Financial Intermediation, Vol. 3, p. 104-137. 
Berger, Allen, Anil Kashyap, and Joseph Scalise (1995), "The Transformation of the U.S. Banking Industry: What a Long, Strange Trip It's Been," Brookings Paper on Economic Activity, vol. 2, 55-218.

Bernanke, Ben (1983), "Nonmonetary Effects of the Financial Crisis in Propagation of the Great Depression," American Economic Review vol. 73, No. 3, 257-76.

Bliss, Robert and George Kaufman (2006), "Derivatives and Systemic Risk: Netting, Collateral and Closeout," Journal of Financial Stability, Vol. 2, No. 1, 55-70.

Blume, Marshall E., Donald B. Keim, and Sandeep A. Patel (1991), "Returns and Volatility of Low-grade Bonds: 1977-1989," Journal of Finance 46, 49-74.

Boyd, John, Sungkyu Kwak, and Bruce Smith (2005), "The Real Output Losses Associated with Modern Banking Crises," Journal of Money, Credit, and Banking, Vol. 37, No. 6, 977-999.

Burns, Arthur F. and Wesley C. Mitchell (1946), Measuring Business Cycles (New York: NBER).

Caballero, Ricardo (2006), "On the Macroeconomics of Asset Shortages," in The Role of Money: Money and Monetary Policy in the Twenty-First Century, The Fourth European Central Banking Conference 9-10 November 2006, Andreas Beyer and Lucrezia Reichlin, editors, 272-283.

Calomiris, Charles and Gary Gorton (1991), "The Origins of Banking Panics: Models, Facts, and Bank Regulation," in Financial Markets and Financial Crises, ed. Glenn Hubbard (University of Chicago Press, 1991).

Cannon, James G. (1910), Clearing Houses (U.S. National Monetary Commission; Washington D.C.: Government Printing Office).

Cerra, Valerie and Sweta Chaman Saxena (2008), "Growth Dynamics: The Myth of Economic Recovery," American Economic Review, Vol. 98, no. 1, 439-457.

Chailloux, Alexandre, Simon Gray, and Rebecca McCaughrin (2008), "Central Bank Collateral Frameworks: Principles and policies," International Monetary Fund, Working Paper \# WP/08/222.

Cornell, Bradford, and Kevin Green (1991), "The Investment Performance of Low-grade Bond Funds," Journal of Finance 46, 29-48.

Cowen, David, Richard Sylla, and Robert Wright (2006), "The U.S. Panic of 1792: Financial Crisis Management and the Lender of Last Resort," New York University, working paper.

Dang, Tri Vi, Gary Gorton and Bengt Holmström (2009), “Notes on Debt: No Title Yet.” 
Davis, Joseph (2006), "An Improved Annual Chronology of U.S. Business Cycles since the 1790s," Journal of Economic History 66: 103-121.

Davis, Joseph (2004), "An Annual Index of U.S. Industrial Production, 1790-1915," Quarterly Journal of Economics 119(4), 1177-1215.

Demirgüc-Kunt, Asli, Baybars Karacaovali, and Luc Laeven (2005), "Deposit Insurance around the World: A Comprehensive Database," World Bank Policy Research Working Paper 3628.

Domanski, Dietrich and Uwe Neumann (2001), "Collateral in Wholesale Financial Markets," BIS Quarterly Review (September), 57-64.

Dunbar, Charles F. (1887), "Deposits as Currency," Quarterly Journal of Economics, Vol. 1, No. 4, 401-419.

Dwyer, Gerald and R. Alton Gilbert (1989), "Bank Runs and Private Remedies," Federal Reserve Bank of St. Louis Review (May/June), 43-61.

Fama, Eugene F., and Kenneth R. French (1989), "Business Conditions and Expected Returns on Stocks and Bonds," Journal of Financial Economics 25, 23-49.

Fama, Eugene F., and Kenneth R. French (1993), "Common Risk Factors in the Returns on Stock and Bonds," Journal of Financial Economics 33, 3-56.

Federal Reserve System (2006), “Consultation Paper on Intraday Liquidity Management and Payment System Risk Policy," Federal Register Vol. 71, No. 119 (June 21, 2006), p. 35679-35687.

Fels, Rendigs (1951), "American Business Cycles, 1865-79", The American Economic Review, Vol. 41, No. 3, pp. 325-349.

Fleming, Michael and Kenneth Garbade (2005), "Explaining Settlement Fails," Current Issues in Economics and Finance (September), Federal Reserve Bank of New York.

Friedman, Milton and Anna Schwartz (1971), Monetary History of the United States, 1867-1960 (Princeton University Press).

Furfine, Craig and Jeff Stehm (1998), "Analyzing Alternative Intraday Credit Policies in Real-Time Gross Settlement Systems," Journal of Money Credit and Banking, Vol. 30, No. 4, 832-48.

Gali, Jordi and Luca Gambetti (2008), "On the Sources of The Great Moderation," National Bureau of Economic Research, Working Paper No, 14171. 
Gorton, Gary (1985a), "Bank Suspension of Convertibility," Journal of Monetary Economics, Vol. 15, No. 2, 177-93.

Gorton, Gary (1985b), "Clearinghouses and the Origin of Central Banking in the U.S.," Journal of Economic History, Vol. 45, No. 2, 277-83.

Gorton, Gary (1988), "Banking Panics and Business Cycles," Oxford Economic Papers 40 (December 1988), 751-81.

Gorton, Gary "Bank Regulation When 'Banks' and 'Banking' Are Not the Same," Oxford Review of Economic Policy (Winter, 1994), Vol. 10, No. 4, 106-119.

Gorton, Gary (1996), "Reputation Formation in Early Bank Note Markets," Journal of Political Economy, Vol. 104, No. 2, 346-397.

Gorton, Gary (1999), "Pricing Free Bank Notes," Journal of Monetary Economics 44, 33-64.

Gorton, Gary (2008), "The Panic of 2007," in Maintaining Stability in a Changing Financial System, Proceedings of the 2008 Jackson Hole Conference, Federal Reserve Bank of Kansas City, 2008.

Gorton, Gary (2009), "Information, Liquidity, and the (Ongoing) Panic of 2007," American Economic Review, Papers and Proceedings, forthcoming 2009.

Gorton, Gary and Lixin Huang (2006), "Banking Panics and Endogenous Coalition Formation," with Lixin Huang, Journal of Monetary Economics, Vol. 53 (7): 1613-1629.

Gorton, Gary and Andrew Metrick (2009), "The Run on Repo and the Panic of 2007-2008," Yale working paper.

Gorton, Gary and Don Mullineaux (1987), "The Joint Production of Confidence: Endogenous Regulation and Nineteenth Century Commercial Bank Clearinghouses," Journal of Money, Credit, and Banking 19:4: 458-68.

Gorton, Gary and George Pennacchi (1990a), "Financial Intermediaries and Liquidity Creation," Journal of Finance 45:1 (March): 49-72.

Gorton, Gary and George Pennacchi (1990b), "Are Loan Sales Really Off-Balance Sheet?," with George Pennacchi, Journal of Accounting, Auditing and Finance 4:2: 125-45.

Gorton, Gary and George Pennacchi (1993a), "Security Baskets and Index-Linked Securities," Journal of Business, Vol. 66, No. 1: 1-29. 
Gorton, Gary and George Pennacchi (1993b), "Money Market Funds and Finance Companies: Are They the Banks of the Future?," in Structural Change in Banking (Irwin Publishing: Homewood, IL; 1993), Michael Klausner and Lawrence White, eds.

Gorton, Gary and George Pennacchi (1993), "Banks and Loan Sales: Marketing Non-Marketable Assets," Journal of Monetary Economics 35(3): 389-411.

Gorton, Gary and Richard Rosen (1995), "Banks and Derivatives," in National Bureau of Economic Research Macroeconomics Annual 1995 (MIT Press).

Gorton, Gary and Nicholas S. Souleles (2006), "Special Purpose Vehicles and Securitization," chapter in The Risks of Financial Institutions, edited by Rene Stulz and Mark Carey (University of Chicago Press; 2006).

Gorton, Gary and Andrew Winton (2003), "Financial Intermediation," in The Handbook of the Economics of Finance: Corporate Finance, edited by George Constantinides, Milton Harris, and Rene Stulz (Elsevier Science; 2003) (NBER Working Paper \# 8928).

Gorton, Gary and Andrew Winton (2000), "Liquidity Provision and the Social Cost of Bank Capital," working paper.

Grossman Richard (1993), "The Macroeconomic Consequences of Bank Failures under the National Banking System," Explorations in Economic History, Vol. 30, No. 3, 294-320.

Gyntelberg, Jacob and Eli M. Remolona (2006), "Securitisation in Asia and the Pacific: Implications for Liquidity and Credit Risks,

Hannan, Timothy and Allen Berger (1991), "The Rigidity of Prices: Evidence from the Banking Industry," American Economic Review, Vol. 81, No. 4, 938-945.

Hollander, J.H. (1913), "Banking Reform-Discussion,” American Economic Review, Vol. 3, No. 1, Supplement, Papers and Proceedings, 64-88.

Holmström, Bengt (2008), "Discussion of 'The Panic of 2007,' by Gary Gorton," in Maintaining Stability in a Changing Financial System, Proceedings of the 2008 Jackson Hole Conference, Federal Reserve Bank of Kansas City, 2008.

Hördahl, Peter and Michael King (2008), "Developments in Repo Markets During the Financial Turmoil," Bank for International Settlements Quarterly Review (December), 37-53.

International Swaps and Derivatives Association (2009), “ISDA Margin Survey 2009." 
James, F. Cyril (1934), "The American Banking Problem," Annals of the American Academy of Political and Social Science, Vol. 171, 1-4.

Kahn, Charles and William Roberds (2001), "Real-Time Gross Settlement and the Costs of Immediacy," Journal of Monetary Economics, Vol. 47, 299-319.

Keeley, Michael (1990), "Deposit Insurance, Risk, and Market Power in Banking," American Economic Review Vol. 80, No. 5, 1183-1200.

Keim, Donald B., and Robert F. Stambaugh (1986), "Predicting Returns in the Stock and Bond Markets," Journal of Financial Economics 17, 357-390.

Kemmerer, E. W. (1911), "American Banks in Times of Crisis under the National Banking System," Proceedings of the Academy of Political Science in the City of New York, Vol. 1, No. 2, 233-253.

Krishnamurthy, Arvind and Annette Vissing-Jorgensen (2008), "The Aggregate Demand for Treasury Debt," Kellogg School, Northwestern University, working paper.

Kwan, Simon H. (1996), "Firm-specific Information and the Correlation Between Individual Stocks and Bonds," Journal of Financial Economics 40, 63-80.

Lerner, Josh (2006), "The New New Financial Thing: The Origins of Financial innovations," Journal of Financial Economics, Vol. 79, 223-255.

Levintal, Oren (2008), "The Real Effects of Banking Shocks: Evidence from OECD Countries," Hebrew University, working paper.

Litzenberger, Robert (1992), "Swaps: Plain and Fanciful," Journal of Finance 47(3), 831-50.

Marburg, Theodore (1908), "The Panic and the Present Depression," Annals of the American Academy of Political Science, Vol. 32, 55-62.

Marcus, Alan (1984), "Deregulation and Bank Financial Policy," Journal of Banking and Finance 8, 557565.

McGrane, Reginald (1924), The Panic of 1837 (Chicago: University of Chicago Press).

Merton, Robert (1992), "Financial Innovation and Economic Performance," Journal of Applied Corporate Finance, Vol. 4, 12-22.

Merton, Robert 91998), "Option-Pricing Theory: Twenty-Five Years Later," American Economic Review, Vol. 88, No. 3, 323-349. 
Miller, Merton (1986), "Financial Innovation: The Last Twenty Years and the Next," Journal of Financial and Quantitative Analysis," Vol 21, No. 4, 459-471.

Miron, Jeffrey and Christina Romer (1990), "A New Index of industrial Production, 1884-1940," Journal of Economic History, Vol. 50, No. 2, p. 321-337.

Moen, Jon and Ellis Tallman (1992), "The Bank Panic of 1907: The Role of Trust Companies," Journal of Economic History 52, no. 3, 611-30.

Molyneux, Phil and Nidal Shamroukh (1996), "Diffusion of Financial Innovations: The Case of Junk Bonds and Note Issuance Facilities," Journal of Money, Credit, and Banking, Vol. 28, No. 3, 502-522.

Neumark, David and Steven Sharpe (1992), "Market Structure and the Nature of Price Rigidity: Evidence from the Market for Consumer Deposits," Quarterly Journal of Economics, vol. 107, no. 2, 657-680.

Noyes, Alexander (1894), "The Banks and the Panic of 1893," Political Science Quarterly, Vol. 9, No. 1, 12-30.

Peltzman, Sam (1965), "Entry into Commercial Banking," Journal of Law and Economics, Vol. 8, 11-50.

Philippon, Thomas and Ariell Reshef (2008), "Wages and Human Capital in the U.S. Financial Industry," NYU working paper, Journal of Finance, forthcoming.

Pozdena, Randall (1986), "Securitization and Banking," FRBSF Weekly Letter, July 4, 1986.

Redlich, Fritz (1947), The Molding of American Banking: Men and Ideas (1968 reprint of 1947 original; Johnson Reprint Corporation: New York and London).

Rezneck, Samuel (1933), "The Depression of 1819-1822, A Social History," American Historical Review, vol. 39, 28-47.

Rezneck, Samuel (1953), "Unemployment, Unrest, and Relief in the United States during the Depression of 1893-97," Journal of Political Economy, Vol. 61, No. 4, 324-345.

Romer, Christina (1994), “Remeasuring Business Cycles,” Journal of Economic History 54(3), 573-609.

Scatigna, Michela and Camilo E. Tovar (2007), "Securitisation in Latin America," BIS Quarterly Review (September), 71-82.

Scholes, Myron (1998), "Derivatives in a Dynamic Environment," American Economic Review, Vol. 88, No. 3, 350-370. 
Seward, Anne (1924), "Bank Runs Rare Now, Owing to Federal Reserve Law," New York Times, March 2, 1924, page XXII.

Silber, William (2007a), "The Great Financial Crisis of 1914: What Can We Learn from Aldrich-Vreeland Emergency Currency?," American Economic Review Papers and Proceedings 97(2), 285-289.

Silber, William (2007b), When Washington Shut Down Wall Street: The Great Financial Crisis of 1914 and the Origins of America's Monetary Supremacy (Princeton: Princeton University Press).

Singh, Manmohan and James Aitken (2009), "Deleveraging after Lehman - Evidence from Reduced Rehypothecation," International Monetary Fund, Working Paper, WP/09/42.

Sprague, O.M.W. (1915), "the Crisis of 1914 in the United States," American Economic Review, Vol. 5, No. 3, 499-533.

Sprague, O.M.W. (1910), History of Crises under the National Banking System, National Monetary Commission, $61^{\text {st }}$ Congress, $2^{\text {nd }}$ Session, Senate document No. 538 (Government Printing Office" Washington D.C.).

Sprague, O.M.W. (1908), "The American Crisis of 1907," The Economic Journal 18, no. 71, 353-72.

Sprague, O.M.W. (1903), "The New York Money Market," Economic Journal, Vol. 13, No. 49, 30-57.

Stevens, Albert C. (1894), "Analysis of the Phenomena of the Panic in the United States in 1893," Quarterly Journal of Economics, Vol. 8, no.2, 117-148.

Stock, James and Mark Watson (2002), "Has the Business Cycle Changed and Why?," NBER Macroeconomics Annual 2002 (MIT Press).

Strahan, Philip (2003), "The Real Effects of Bank Deregulation," Federal Reserve Bank of St. Louis Economic Review Vol. 85, No. 4 (July/August), p. 111-128.

Summers, Peter (2005), "What Caused The Great Moderation? Some Cross-Country Evidence," Economic Review, Federal Reserve Bank of Kansas City (third Quarter), 6-32.

Swanson, William Walker (1908a), "The Crisis of 1860 and the First Issue of Clearing-House Certificates: I," Journal of Political Economy, Vol. 16, No. 2, 65-75.

Swanson, William Walker (1908b), "The Crisis of 1860 and the First Issue of Clearing-House Certificates: II," Journal of Political Economy, Vol. 16, No. 4, 212-226. 
Taggart, J.H. and L. D. Jennings (1934), "The Insurance of Bank Deposits," Journal of Political Economy, Vol. 42, No. 4, 508-516.

Thomas, R.G. (1935), "Bank Failures-Causes and Remedies," The Journal of Business of the University of Chicago, Vol. 8, No. 3, 297-318.

Tufano, Peter (2004), "Financial innovation," in The Handbook of the Economics of Finance, ed. By George Constantinides and Rene Stulz (North Holland).

Valencia, Fabian (2008), "Banks' Precautionary Capital and Persistent Credit Crunches," International Monetary Fund, Working Paper \# WP/08/248.

Wallis, John Joseph (2001), “What Caused the Crisis of 1839?," NBER Historical Paper No. 133.

Wang, Feng (2004), "Throwing Bricks, Attracting Jade - Securitization of Non-Performing Loans in China," working paper.

Weston, N.A. (1922), "The Studies of the National Monetary Commission," Annals of the American Academy of Political and Social Science, Vol. 99, 17-26.

Yu, Fan (2005), "How Profitable is Capital Structure Arbitrage?," University of California, Irvine, working paper.

Zhou, Ruilin (2000), "Understanding Intraday Credit in Large-Value Payment Systems," Federal Reserve Bank of Chicago, Economic Perspectives, Vol. 24, 29-44. 